\title{
Beyond the Overall Economic Downturn: \\ Evidence on Sector-specific Effects of Violent Conflict from Indonesia
}

\author{
Marc Vothknecht* \\ German Institute for Economic Research (DIW Berlin) and \\ Humboldt University Berlin \\ Sudarno Sumarto \\ SMERU Research Institute and \\ Stanford University \\ *Corresponding author: mvothknecht@diw.de
}

January 2009 


\begin{abstract}
This paper analyses the impact of violent conflict on economic growth using a unique dataset from the villages of Indonesia. We compile a panel dataset at district level for the period 2002-2008, and disentangle the overall negative economic effect of violent conflict into its sectoral components. Our results reveal substantial differences across sectors, with manufacturing industries and the service sectors being most affected. The short-run impacts on growth thereby appear to be only temporal, and some evidence for the 'phoenix effect' in the early post-conflict period is found. A series of alternative specifications confirm the main findings of the analysis.
\end{abstract}




\section{INTRODUCTION}

Indonesia, the largest and most populous Southeast Asian nation, emerged with a new democratic government in 1998 following the fall of President Suharto. The collapse of his long and authoritarian New Order regime was followed by a wave of high-profile violence, with separatist conflicts in Aceh and East Timor, religious conflicts in Maluku and Sulawesi, and ethnic conflicts in Kalimantan and Nusa Tenggara Timur. One decade after Suharto's fall, some progress in restoring peace and political stability has been achieved, Indonesia is moving towards having a more stable democratic government, and the number of headlinemaking conflicts has decreased sharply.

This paper investigates the conflicts' economic consequences, which have not yet been analyzed systematically. We use district-level data on GDP composition and a nation-wide dataset on the occurrence of conflict in 2002, 2005, and 2008 in order to shed light on the specific effects of violent conflict on different economic sectors. While existing empirical evidence on the conflict-growth nexus mostly comes from cross-country studies based on aggregate GDP data, this approach allows going beyond the overall negative impact of war. Panel analysis reveals those activities which depend on capital and transactions to be particularly vulnerable to violent conflict. Spillover effects from violence in neighboring regions are less clear and appear to only affect transaction-intensive sectors, most notably transport industries and financial services. In general, conflict-related negative growth effects are of temporary nature, with some areas of the economy recovering faster than others once conflict ends. The results further confirm that violence intensity matters for the scale of the economic downturn, rather than the mere existence of mostly non-violent or low intensity conflicts.

The paper is structured as follows. The next section reviews the existing literature on growth and violence, discusses potential transmission channels, and derives some hypotheses on the sector-specific impacts of violent conflict. We then turn to the data, present some descriptive statistics, and provide background information to the conflicts under consideration. This is followed by a discussion of the estimation strategy, the presentation of the regression results, and some concluding remarks.

\section{BACKGROUND}

\section{Growth Empirics}

Explaining differences in economic growth and, more general, in income levels across 
countries and over time is one of the most important, though also one of the more difficult tasks in economic research. The existing literature is vast and constantly amended by new contributions to both theory and empirics. Solow's (1956) model still constitutes the major theoretical reference and the basic workhorse of growth empirics. Based on a neoclassical production function with diminishing returns to scale, long-run per capita incomes in this model depend on saving and population growth rates as well as technological progress. Countries with similar characteristics in this respect are expected to converge to a common steady state, with only transitory income differences between these countries. This neoclassical theory of convergence has been challenged by the divergent growth experiences in the real world, and permanent income differences between countries have additionally been attributed to structural and institutional heterogeneities.

This is in line with extensive empirical work that has found a wide range of economic, political, social and geographical factors to affect economic growth. ${ }^{1}$ The validity of this large amount of work, however, with a variety of different and sometimes opposing results, has increasingly been called into question. Inter alia, criticism include arbitrary model specifications without theoretical underpinning, issues of data comparability, inappropriate econometric methodologies, limitations of cross-country analyses, and insufficient treatment of endogenous explanatory variables (see e.g. Bosworth and Collins, 2003). Recent work has tried to account for these shortcomings, and Durlauf et al. (2005) identify a set of explanatory variables that has consistently been found to be related to economic growth. While the focus of this study is on violent conflict rather than on the growth process as such, cross-country evidence on these factors is briefly reviewed.

Today, scholars widely agree on the importance of institutional settings for economic development. Acemoglu, Johnson, and Robinson (2004) stress the role of economic institutions, such as well-defined property rights and the presence of functioning markets for economic outcomes. The quality of economic and also political institutions and its impact on economic growth has been assessed by a wide range of studies. Acemoglu, Johnson, and Robinson (2001), for instance, tackle concerns of endogeneity by using the mortality of colonial settlers as an instrument for today's institutional quality and confirm a decisive impact on growth. Beside of historical legacies, ethnic diversity is often seen as another explanation for cross-country differences in the effectiveness of public policies. Heterogeneous preferences across ethnic groups are likely to impede agreement on policy

\footnotetext{
${ }^{1}$ Durlauf, Johnson, and Temple (2005) report a total of 145 potential determinants of economic growth that have been studied in the literature.
} 
decisions and result in lower spending on public goods (Alesina, Baqir, and Easterly, 1999). Sound government policy thereby plays a particularly decisive role in the area of infrastructure. Efficient investments for example in telecommunications, transport, water or energy systems facilitate economic activity and have been found to contribute substantially to GDP growth (Esfahani and Ramírez, 2003).

The relationship between education and economic growth is more contested. While a positive link between individual education and income is confirmed by a large body of microeconomic studies (see e.g. Psacharapoulos and Patrinos, 2004), cross-country evidence is mixed. Recent macro-level analyses on the impact of educational attainment on economic growth have failed to establish a significant relationship (see Easterly and Levine (2001) for a discussion). Differences between social and private returns to education, measurement errors and limited data comparability are potential explanations. Other country characteristics that have been identified as fundamental growth determinants, such as climatic conditions (Masters and McMillan, 2001), geographic isolation (Frankel and Romer, 1999), or culture and religion (Barro and McCleary, 2003) are rather time-invariant and can hardly be influenced at least in the short run.

In general, cross-country studies tend to focus on those factors that drive growth in the long run and rarely provide scope for short term interventions. A distinction between short term growth dynamics and long-run equilibrium effects could therefore add valuable insights for policy makers (Rao and Corray, 2009). Evidence from cross-country studies often also suffers from restrictive assumptions. Pooling across countries implicitly assumes a universal growth process and homogeneous growth parameters, i.e. identical underlying production functions and technological improvements. With most samples, however, consisting of very heterogeneous countries at different stages of development and with diverse economic structures, cross-country parameter estimates at best display inter-country averages, but tell little about the evolution of growth in a single country (Bos et al., 2010).

Therefore, 'case studies' using country specific time series or panel data are more appropriate when analyzing country specific growth experiences. Common institutional and legal frameworks and the consistency of data sources within countries contribute to a higher comparability of growth processes. Disaggregated GDP data often also allows investigating inter-industry differences. For Indonesia, Garcia and Soelistianingsih (1998) analyze the evolution of provincial incomes under the New Order regime and find poorer provinces to catch up especially through investments in human capital. Using district-level data for the period 1993-2005, McCulloch and Sjahrir (2008) confirm the hypothesis of relative 
convergence and the positive growth impact of a better educated labor force.

\section{Impact of Violent Conflict on Growth}

Violent conflicts affect economic outcomes mainly through the destruction of human and

physical capital, shifts in public spending and private investment, and the disruption of economic activities and social life (see Blattman and Miguel (2009) for a summary). The particular impacts thereby depend on each conflict's singular characteristics. The type of conflict, its intensity, duration, and geographical spread all shape its economic consequences. We would also expect that violent conflicts affect different economic sectors differently. Quantitative evidence on the overall growth effect of conflicts mostly comes from crosscountry datasets. Collier's (1999) analysis establishes a substantially negative link between civil war duration and economic growth. His approach, however, has been criticized for not considering variations in the scale and scope of conflict. Imai and Weinstein (2000) stress the importance of the geographical spread of conflicts, and conclude that wide-spread civil wars affect economic growth five times more than conflicts fought in small parts of the country. Bodea and Elbadawi (2008) distinguish different levels of political violence and reveal a particularly negative growth impact of civil wars, relative to the less severe effects of riots or coups. In line with this, Koubi (2005) finds long-run economic growth the more affected by civil wars the more severe they are in terms of conflict-related human losses.

Single country evidence on the growth impact of violence is relatively scarce. Abadie and Gardeazabal (2003) show a negative impact of the ETA terrorist conflict on economic growth in the Basque Country. Dependent on the intensity of terrorism, Basque per capita GDP declined on average by 10 percentage points relative to other Spanish regions. Lopez and Wodon (2005) use time series data to estimate the impact of the 1994 genocide on the evolution of Rwanda's per capita GDP. Based on outlier detection and correction, their results indicate a significant loss in GDP in the short run, though no impact on post-genocide growth rates. Arunatilake, Jayasuriya and Kelegama (2001) assess the direct and indirect costs of the Sri Lankan civil war between 1983 and 1996, with their estimates of total costs adding up to twice the country's 1996 GDP.

Existing literature on Indonesian conflicts mostly deals with the socioeconomic determinants of violent conflict and not with its consequences (Tadjoedin and Murshed, 2007). Barron, Kaiser and Pradhan (2009) use the 2003 PODES village dataset to analyze correlations of local violent conflicts with several socioeconomic variables, including unemployment, inequality, and natural disasters. Anecdotal evidence reveals that the economic potential of 
conflict prone areas was not fully realized due to conflicts. Most production in these areas has been disrupted and those who tried to export their products faced barriers such as illegal taxes or fees imposed by civil servants and military personnel (Mawardi, 2006).

Often, the economic impact of violent conflicts is not limited to the conflict area, but spills over to neighboring regions and countries. Refugee flows increase labor supply and reduce per capita incomes, trade flows are disrupted, government spending is diverted to nonproductive security measures, and foreign direct investments might be shifted away from the whole region perceived as insecure. Murdoch and Sandler's (2002) analysis of spatial dispersion finds significant negative growth impacts of civil wars for contiguous neighbors, especially in the short run. Using different data and methodology, de Groot (2010) confirms the negative economic effects of violent conflict for direct neighbors, however, finds positive spillovers for non-contiguous areas.

\section{Transmission Channels from Conflict to Growth}

What are the main mechanisms through which violent conflict affects the economy? First and foremost, the level and the growth rate of the capital stock are negatively affected by conflictrelated damage and reduced investment. The destruction of production facilities and key infrastructure, most notably in the areas of transportation, communication and energy, impedes economic activity. Private agents involve in dissaving and portfolio substitution as the perceived risk increases and investments in regions not affected by violent conflict offer higher relative returns at lower risk. Government spending on productive activities is likely to decrease due to an eroding tax base and hampered tax administration on the one hand and the diversion of public funds to military and security expenditures on the other. Poor macroeconomic policy with rising budget deficits and increasing inflation tend to further hamper economic growth.

Empirical work mostly focuses on changes in public and private investment. Svensson (1998), for instance, identifies a potential channel from political instability and associated weak property rights to reduced private investment. A negative impact of political violence on private savings and domestic investments is also found by Fielding $(2000,2004)$ in his analyses of the macroeconomic impacts of the Israeli Intifada. Gupta et al. (2004) reveal adverse effects of armed conflict on tax revenues and public investments: higher government spending on defense is associated with macroeconomic instability and a diversion of

resources away from socially and economically productive sectors. Knight, Loayza, and Villanueva (1996) relate this growth-retarding impact of rising military expenditures to 
negative effects on capital formation and resource allocation. Imai and Weinstein (2000), finally, conclude that reductions in private investments affect economic growth much more than downturns in public investment.

Assessing the growth impact of other conflict phenomena, such as the loss of human capital or changes in economic activities, has proven more difficult. People living in conflict zones face increased risks of being injured or killed, and especially the better-off (and better educated) might choose to flee to neighboring regions or countries. In the longer run, human capital accumulation is affected by the destruction of educational infrastructure, the absence of teachers, and lower government spending on education during war times. The negative long-term consequences of civil wars for aggregate health and education measures are documented by an increasing number of studies. ${ }^{2}$ In the short run, conflict-related deaths and injuries, emigration, displacement and forced recruitment reduce the available labor force and are likely to affect productivity. However, systematic empirical evidence on the impact of violent conflict on labor markets hardly exists. One exception is Arunatilake et al.'s (2001) assessment of the costs of the civil war in Sri Lanka. Their estimates of the costs related to displacement and lost human capital sum up to around five per cent of the estimated total costs of war.

More is known on conflict-related distortions of economic behavior, i.e. impacts on economic activity and market exchange. Heightened insecurity, threatened property rights, and the suppression of civil liberties result in an unsafe business environment. Transaction costs increase, trust deteriorates, economic activities are disrupted and market exchange is limited in war-torn societies. Micro-level studies document people's retreat into less vulnerable economic activities in conflict regions. Deininger (2003), for example, shows that the civil strife in Uganda during the 1990s reduced off-farm investments and led to a shift towards subsistence farming and less integration to markets. Similarly, Verpoorten (2009) finds that Rwandan households most affected by violence were prevented from selling their cattle, which is usually done as a response to adverse income shocks, due to unsafe roads and the related non-accessibility of markets. Violent conflict thereby hampers not only domestic exchange, but international trade flows as well. Blomberg and Hess (2006) find that global trade flows are more impeded by violent conflicts than by traditional tariff barriers. According to their estimates, bilateral trade flows of conflict-affected countries decline by up to 40 percentage points. The strong negative impact of war on international trade is confirmed by

\footnotetext{
${ }^{2}$ Ghobarah, Huth \& Russett (2003) examine the impact of civil wars on public health; Lai and Thyne's (2007) cross-country study finds devastating war effects on educational systems.
} 
Glick and Taylor's (2005) related analysis for the period 1870-1997.

\section{Sector-specific Evidence and Expectations}

Given the substantial and diverse effects of violent conflict, we would expect varying degrees of vulnerability across different economic sectors. Empirical evidence on such sector-specific effects of violent conflict is generally rare, as disaggregated growth measures from war-torn economies are mostly not available. Collier (1999) argues that those activities which either supply or are intensive in either capital or transactions are particularly vulnerable. Sectors less dependent on capital and transactions are expected to be relatively less affected, which applies to and is confirmed by the observed rise in subsistence agricultural activities in times of conflict.

The overall conflict impact on primary sector growth, however, seems ambiguous. Destroyed assets, landmine contamination, and a shortage of labor and capital are likely to impede agricultural development. The production of (cash) crops and livestock requires future investments and is expected to decline due to shortened planning horizons of farmers. Dramatic losses of livestock are documented for several civil wars. ${ }^{3}$ Teodosijević (2003) compares growth rates of agricultural production in 38 conflict-affected countries and finds substantially lower outcomes during violent conflict as compared to the pre-war period. In general, concerns of endogenous economic outcomes with respect to violent conflict particularly apply to the primary sector. Being central to many societies in the developing world, environmental scarcities and food insecurities are among the main triggers of today's violent conflicts. Prospects for agricultural development might therefore be structurally lower in conflict-prone regions.

Similarly, the link between natural resource wealth and violent conflict is likely to run in both ways. Scholars have found the production of oil and 'lootable resources', such as gemstones and drugs, to be associated with the incidence especially of separatist conflicts (see Ross (2004) for a summary). Violent conflicts, in turn, tend to increase the economic dependency on natural resources. While other sectors of the economy collapse, natural resources are immobile and represent an often important source of revenue for governments and/or rebels. Official growth rates of the mineral sector then also depend on the legal status of the profiteer and the perceived legitimacy of extraction.

Turning to the industrial sector and applying Collier's (1999) hypotheses of war vulnerability,

\footnotetext{
${ }^{3}$ Brück (1997) estimates a loss of $80 \%$ of the cattle stock in the Mozambican civil war. Similar devastation is found for Uganda (Annan, Blattman, and Horton, 2006) and Rwanda (FAO, 1997).
} 
we would expect manufacturing and construction industries to be particularly affected. Manufacturing is often intensive in both physical and human capital, requires complex coordination with contractors and vendors, and is therefore especially reliant on the institutional environment. In his analysis of conflict-ridden developing countries, Depetris Chauvin (2009) points to negative war effects for exporting industries due to conflict-related trade barriers. The collapse of the domestic demand for investment goods, both from state and private actors, would also and in particular affect the construction sector.

The service sector compasses a broad range of economic activities, ranging from traditional services - housecleaning, food services, barber shops, and the like - to trade, transport, tourism, the social sector, and finance and business services. Finance is expected to suffer from capital flight and falling demand for transactions, with the latter also applying to trade and transport industries. Likewise, tourism is particularly sensitive to events of violence: Neumayer's (2004) cross-country analysis reveals strong negative impacts of political violence on tourist arrivals, with even stronger impacts in the long run compared to contemporaneous effects. Increasing military expenditures during violent conflict involve shifts in government spending often to the detriment of social services. Traditional services tend to be location-specific and are less dependent on physical capital and long-term investments. Assumed to be relatively war-invulnerable, such local services might nevertheless suffer from the overall economic decline. Generally, the lack of employment opportunities in conflict times often leads to an increase in informal businesses. These activities, such as petty trade, peddling work or the selling of food, however, are difficult to capture in official statistics.

An important issue omitted so far is the dynamic aspect of violent conflict, i.e. varying economic impacts at different stages of conflict. Disregarding conflict intensity, the negative shock related to the outbreak of violence might have a more detrimental growth impact than ongoing conflict. Cerra and Saxena (2008), for instance, show that the initial economic decline in countries affected by civil war is substantial, but expect an at least partial recovery of output levels after a relatively short period of time. Contrary to the convergence predictions of neoclassical growth models, however, a complete catch-up to pre-war levels in the postconflict period is not observed. With reference to the Phoenix factor theory (Organski and Kugler, 1980), we would still expect positive prospects for economic growth in the recovery process. Efforts of reconstruction, for instance, might spark a construction boom once violence and insecurity decline (Collier, 2009). Other areas of the economy, such as the tourism industry or the financial sector, might be more reliant on the rebuilding of trust and a 
peaceful environment.

\section{DATA AND CONFLICT DESCRIPTION}

\section{Growth Data}

Data on economic growth is provided by BPS. [...] The data is disaggregated at district and sectoral level. Table I in the Appendix provides an overview of the different sectors, subsectors, and sub-categories, and reports the sectoral shares of total GDP in 2000 and 2008. We distinguish the primary, secondary, and tertiary sector, and additionally disaggregate into the following nine sub-sectors: agriculture, mining, manufacturing, energy, construction, commerce, transport and communication, finance, and other services. Manufacturing constitutes the most important sub-sector and accounts for one quarter of total GDP. The total share of the tertiary sector has increased from 40 per cent in 2000 to 45 per cent in 2008 . In rural areas, the importance of agriculture has decreased only slowly since 2000 , and the sector still accounts for 26 per cent of total rural production in 2008.

For each category, we calculate the annual rate of GDP growth. While comparisons with other sources on the Indonesian GDP confirm the overall accuracy of the data, calculations of growth rates give implausible results for a few districts and sub-sectors. These extreme growth rates are distributed rather randomly across districts and sectors; e.g. a district with very high growth in the transport sector reports moderate growth rates in all other sectors. The correction of extreme sub-sectoral growth rates should therefore not involve systematic distortions of the data, and we adjust outliers (growth rates larger than 50 per cent) in the following way: a) in cases where the current GDP value deviates extremely from the general trend, the average growth rate from the last two years is used; b) sub-sectors with growth rates larger than 50 per cent are excluded from the calculation of sectoral (agriculture, industry, services) and overall growth. This procedure results in the adjustment of 99 sub-sectoral growth rates in total, which corresponds to less than one per cent of the whole sample. For robustness purposes, we still rerun the analysis with the original data.

Table 1a provides descriptive statistics for the adjusted variables of economic growth. Apart from five missing observations, ${ }^{4}$ a balanced panel is available. In order to control for economic spillover effects, we also calculate the average weighted growth rate in neighboring districts in the current and preceding year. Figure 1 displays the evolution of sectoral and

\footnotetext{
${ }^{4}$ Control variables are not available from the district of Nias (North Sumatra). GDP growth rates can not be calculated for the newly founded districts of Kota Bengkulu (Bengkulu) and Kota Bau-Bau (South East Sulawesi) for 2002, as GDP data for 2001 is not available.
} 
overall GDP growth rates in Indonesia for the period 2001-2008. Overall annual growth appears relatively stable at around five per cent and increases slightly over time. The service sector is the main driver of the Indonesian economy with average annual growth rates above six per cent.

\section{PODES Data}

Control and conflict variables are derived from the Village Potential Statistics Survey (Potensi Desa or PODES). This village-level census is conducted on a regular basis by the Central Bureau of Statistics (BPS) and collects socio-economic information from all 69,000 Indonesian rural villages and urban neighborhoods. Based on responses of the village heads, the survey includes a wide range of indicators, ranging from population characteristics to infrastructure, economic activities, and social life. We use three subsequent rounds of PODES (2003, 2006, 2008), collected in August 2002, between July and September 2005, and between April and Mai 2008, respectively. We aggregate the PODES data at district level, the administrative level for which economic growth data is available. A challenge in constructing the database arises from Indonesia's decentralization program and the related formation of new districts. This process know as pemekaran has led to an increase in the number of districts from 376 in 2002 to 438 in 2005, and 465 in 2008 . We therefore rearrange the 2005 and 2008 data to the 2002 district borders in order to achieve a uniform dataset of 376 districts throughout.

Table $1 \mathrm{~b}$ presents basic descriptive statistics. While some of the standard controls in crosscountry growth regressions are not available at district level, ${ }^{5}$ the detailed village-level information provided by the PODES data allows obtaining a reasonable set of proxy variables. We use the share of villages with electricity and the average educational attainment of village heads in a district to proxy for infrastructure development and institutional quality, respectively. Further control variables are the rate of population growth, ethnic diversity, natural disaster events, and an indicator for the physical damage caused by the 2004 Indian Ocean tsunami.

In 2003 PODES, a section on conflict has been included for the first time. The village heads report, inter alia, on incidences of conflict in the previous year, the number of conflict victims, the amount of conflict-related material damage, and whether the conflict has been solved or is

\footnotetext{
${ }^{5}$ For instance, no measure of human capital is included, as data on literacy or school enrolment rates have not yet been available for 2008. Given the relatively short time period that is covered by the analysis, however, we do not expect these indicators to change substantially. In fact, the variance decomposition of available literacy data from 2000 to 2006 reveals low within district variations as compared to the variation across districts.
} 
still ongoing. Table 1c provides descriptive statistics for all conflict variables that we use in the analysis, aggregated at district level. In order to obtain comparable indicators of conflict intensity, fatalities and material damage are set in proportion to the district's total population and total GDP, respectively. Conflict spillover variables are computed by the ratio of the total number of fatalities (total amount of material damage) in all neighboring districts to the total population (total GDP) of all neighboring districts. Unlike binary indicators used in related cross-country analyses, this approach allows considering the economic impact of conflict intensity in neighboring regions.

Table 2 summarizes the occurrence of conflict over time, as reported by village heads. We observe a substantial decrease in both the spread and the intensity of violence in 2005 and 2008, as compared to $2002 .{ }^{6}$ While 7.2 per cent of all villages and neighborhoods report conflict in 2002, this share is halved in 2005 and 2008. Even more striking is the decline in conflict-related human losses and physical destruction over time: Fatalities and material damage in 2005 and 2008 each sum up to only about one tenth of the 2002 figures, which documents Indonesia's peaceful development in recent years. Still, these low levels of reported conflict also raise concerns of misreporting by local authorities, and comparisons with other quantitative surveys and qualitative fieldwork indeed suggest that conflict is significantly underreported by PODES. ${ }^{7}$ However, these comparisons also show such underreporting to be of similar magnitude across different regions and hence not biased by local characteristics. We therefore assume the PODES data to provide accurate information on relative levels of conflict both across districts and over time.

Figure 2 maps the distribution of violence across Indonesia for 2002, the year in the sample in which by far most of the violence took place. Figure 2 a depicts conflict in terms of fatalities per capita, Figure $2 b$ shows conflict intensities in terms of material damage relative to district GDP. Conflict-related fatalities are relatively concentrated and particularly present in the entire province of Aceh as well as on the islands of Maluku, North Maluku, and Sulawesi. High levels of physical destruction are, in addition, observed in the province of Jambi and on the islands of Nusa Tenggara, while almost no material damage is reported from the western coast of Aceh. Table 3 lists the districts which are most affected by violence, with

\footnotetext{
${ }^{6}$ Village heads were asked for incidents of conflict in the previous year, which hence relates to conflicts in the periods September 2001-August 2002, July/October 2004-June/September 2005, and Mai/June 2007-April/Mai 2008. For simplicity, we refer to conflicts in 2002, 2005, and 2008, respectively.

${ }^{7}$ Barron and Sharpe (2008) monitor conflicts reported in local newspapers in the provinces of East Java and Nusa Tenggara Timur (NTT) during the period 2001-2003; Barron, Kaiser and Pradhan (2004) conduct villagelevel case studies in the same provinces for comparison with 2003 PODES.
} 
observations almost exclusively from 2002 and from rural areas. In fact, only ten per cent of overall fatalities and seven per cent of overall material damage are reported from urban areas. The figures also confirm the different distribution of human losses and destroyed physical capital. A substantial share of those districts with high numbers of fatalities is comparatively little affected in terms of physical destruction, and vice versa (correlation between reported material destruction and fatalities: 0.66 ). We use this variation to analyze potentially different economic impacts of different forms of violence.

\section{Background to the Violence}

To set the violence in context, we briefly characterize the most severe conflicts that plagued the early years of the post-Suharto era and account for most of the violence observed in 2002. Most international attention has been paid to the conflict between the Free Aceh Movement (GAM) rebels in Aceh and the Indonesian government (see Reid (2006) for an in-depth analysis of the conflict). This fight for separatism began with GAM's declaration of an independent Aceh in 1976 and has lasted for almost 30 years, with an estimated 12,000 being killed during the conflict. A province rich in oil and gas, with a long history of independence and a regional specific Muslim character, Acehnese aspirations for political autonomy were based on economic as well as historical and religious reasons. Suharto's military regime responded to the secessionist movements with increasingly repressive measures, while at the same time absorbing the lion's share of the province's remarkable revenues from oil and gas.

The fall of Suharto in 1998 raised hope to bring an end to the conflict, peace talks between the democratically elected Indonesian Government and GAM were initiated, and a special autonomy status was offered to the province. At the same time, fighting between GAM rebels and the Indonesian military continued and even intensified between 1999 and 2002, causing a high death toll also and especially among civilians. When peace talks finally failed, Jakarta imposed martial law on Aceh in Mai 2003 and started a major military offensive to ultimately weaken the rebel movement. Growing battle fatigue among GAM members and the newly elected President Yudhoyono's and Vice President Kalla's political will to end the conflict then contributed to a tentative resumption of the peace process in late 2004. It was in this context, when Aceh was hit by the devastating tsunami in late December 2004, which struck much of the western and northern coast of the province. Both belligerent sides agreed on ceasing hostilities to facilitate the recovery process, and the subsequent peace talks resulted in the Helsinki peace agreement in August 2005. Since then, Aceh has entered a period of relative peace. 
The separatist movement in Aceh has not been the only conflict post-Suharto Indonesia has had to deal with. Suppressed by the New Order's military might, long-simmering tensions finally broke out into overt conflict and destructive violence during the country's transition to democracy and decentralization. While conflicts occurred throughout the archipelago, some regions were particularly affected by violence. In the provinces of Maluku and North Maluku, tensions between religious and migrant groups caused over 7,000 deaths between 1999 and 2002 (see Brown, Wilson and Hadi (2005) for a conflict overview). Populated rather equally by Muslims and Christians, historical inequalities stemmed from preferential treatment of Christians during Dutch colonialism. The political, social and economic dominance of Christians, however, began to erode under the Islamization policies in the last decade of the New Order regime, when Muslims were increasingly appointed to key positions in the civil service. Continued influx of mostly Muslim migrants from Java and Sulawesi further challenged the fragile ethno-religious balance, and resulting tensions over communal land and resources were aggravated by the 1997 economic crisis.

A fight between an Ambonese Christian bus driver and an immigrant Muslim in January 1999 finally triggered a period of wide-spread inter-communal violence that quickly spread to other parts of the province. The initial disinterest or even active involvement of security forces contributed to an escalation of violence, and the conflict further intensified in mid-2000, when several thousand fighters of the newly-founded Islamic militia organization Laksar Jihad entered the region to support the Muslim side. The central government's build-up of security forces and the later Vice President Kalla's efforts in mediating peace finally resulted in the Malino II peace agreements in February 2002. While this peace has been fragile and occasional violence has continued well after the agreement, conflict has been considerably less intense in recent times (Varshney et al., 2009).

Comparable patterns of violence evolved on Sulawesi, located to the west of the Maluku islands, and particularly in the province of Central Sulawesi. For similar reasons, ${ }^{8}$ tensions between Christians and Muslims increased during the 1990s and gave way to severe sectarian violence in the post-Suharto period, with an estimated 1,000 killed and 100,000 displaced (see e.g. Human Rights Watch (2002) for a conflict overview). Absent effective security forces and functioning legal institutions, the conflict went through different phases and intensified further with the arrival of Laskar Jihad fighters in mid-2001. The increased presence of police

\footnotetext{
${ }^{8}$ Similarities in the underlying causes of the violence in the Moluccas and in Central Sulawesi include historical socio-economic imbalances, shifts in local power from Christians to Muslims as a result of Suharto's 'Islamic Turn' in the 1990s, spontaneous and government-led in-migration of Muslims mainly from South Sulawesi and Java, as well economic uncertainty in the wake of the 1997 economic crisis.
} 
and military personnel and the central government's efforts to mitigate the conflict finally led to the Malino peace declaration in December 2001. The number of communal clashes has since declined substantially; incidents of violence, however, have still occurred sporadically and peace has remained vulnerable.

The outlined conflicts in Aceh, Maluku, and Sulawesi account for 89 per cent of total fatalities (per capita) and 67 per cent of total material damage (relative to the district's GDP) reported by village heads in 2003 PODES. Conflicts reported outside these areas are spread across the archipelago, with more pronounced levels of violence in the Nusa Tenggara islands, parts of Java and Central Sumatra, as well as Papua. Underlying causes of these low intensity conflicts appear to be manifold and related to local circumstances (Barron et. al, 2009). Generally, a lack of effective institutions, local power struggles in the process of decentralization, and conflicts related to land ownership and usage seem to have been the most prominent drivers of communal violence in Indonesia. However, it has to be noted that the majority of districts is hardly affected by any conflict even in 2002, when 81 per cent of the districts reported less than five conflict-related fatalities.

\section{EMPIRICAL RESULTS}

\section{Econometric Approach}

Building on standard growth regressions, the starting point of our empirical analysis is the following equation:

$$
g_{i t}=C_{i t} \alpha+X_{i t} \beta+\varepsilon_{i t},
$$

where $g_{i t}$ is the total or sectoral growth rate of real GDP in district $\mathrm{i}$ and year $\mathrm{t}, C_{i t}$ are measures of conflict, $X_{i t}$ is a matrix of other covariates that determine economic growth, and $\varepsilon_{i t}$ is the unobservable error term. The coefficient of interest is $\alpha$, which captures the effects of conflict on GDP growth. Previous macro-level studies on the economic impacts of violent conflict have in large part relied on pooled OLS estimation (Bozzoli et al., 2008). In this setting, however, the underlying assumption of independent and identically distributed errors $\varepsilon$ is likely to be violated.

First, when factors are omitted that affect a society's economic outcomes and its vulnerability to violent conflict at the same time, OLS estimates are inconsistent. Cultural attitudes, for instance, are hardly measurable, but potentially drive both growth and conflicts. Given the panel structure of the data, a way of dealing with such unobserved heterogeneity is the introduction of district fixed effects (FE) to control for those district characteristics which have not changed over the 2002-2008 survey period. This captures underlying cultural values, 
as well as other time-invariant or long-term and hence slowly-changing growth determinants, such as initial wealth or geographic and climatic conditions. The inclusion of time dummies accounts for overall macroeconomic trends that affect all districts alike. Therefore, only additional explanatory variables that vary both with district and over time need be included for the analysis of short-term and within-district growth dynamics. The variance decomposition for the growth and conflict variables consistently reveals more variation over time (within variation) than across districts (between variation), which confirms the accuracy and necessity of the FE model for our particular focus on the role of violent conflicts.

Second, as every empirical investigation of the conflict-growth nexus, we face concerns of reverse causality. That is, (low) economic growth is not only a result, but also a potential cause of violent conflict, leading to inconsistent parameter estimates. Ideally, we would like to instrument for the endogenous variable(s) to disentangle simultaneous causation. However, finding suitable "instruments", which predict the incidence or even intensity of violent conflict and are uncorrelated with the error term, has proven to be extremely difficult. Instruments for conflict proposed by the literature include agricultural growth, urban population, and tropical location (Kang and Meernik, 2005). The size of the population and the geophysical environment might be considered as further potential IV candidates. ${ }^{9}$

All these instruments seem neither valid nor relevant. While the required exogeneity with respect to economic growth is disputable, their explanatory power in predicting violence appears even more problematic. The outbreak and the course of violent conflict are in general highly complex phenomena. The attempt to capture these processes with only one or a few proxy variables inevitably runs the risk of oversimplification and misframing. ${ }^{10}$ As convincing instruments are hardly imaginable, we forego the IV approach and investigate potential reverse causality from growth to conflict in more detail for the Indonesian context.

As outlined in the previous section, the underlying reasons for the conflicts in Indonesia at the turn of the millennium are multifarious and even varying across the affected regions. While the conflict in Aceh has been driven by the long quest for (more) independence, the widespread communal violence has mainly arisen from latent tensions related to horizontal

\footnotetext{
${ }^{9}$ Collier and Hoeffler (2004) find population size to be an important determinant of war, with more populous countries being more prone to conflict. Fearon and Laitin (2003) stress that mountainous terrain (similar: forest coverage) can facilitate civil wars, as rough terrain provides sanctuary to rebels.

${ }^{10}$ Potential reverse effects from growth to conflict are likewise contested. In an innovative approach, Miguel, Satyanath and Sergenti's (2004) use abrupt declines in rainfall in Sub-Saharan Africa, where economies primarily rely on rain-fed agriculture, to instrument for economic growth. While they find a negative impact of economic growth on conflict incidence, this result, however, seems to not hold when a more appropriate subsample of states with conflict on their own territory is used - as opposed to the inclusion of states that send troops to conflicts in other states (Jensen and Gleditsch, 2009).
} 
inequalities and large-scale migration, the lack of effective security and justice institutions, and local-level struggles for economic power in the process of decentralization. Economic uncertainties in the wake of the financial crisis certainly contributed to the outbreak of violence in 1999, and disappointing economic developments thereafter are likely to have affected people's readiness to engage in conflict.

However, and focusing on the first PODES wave we use, GDP growth in 2002 seems at least not among the most obvious drivers of the reported violence. First, as conflicts reported in 2003 PODES refer to the period September 2001 to August 2002, the analysis captures the impact of conflict on slightly lagged growth. This is especially true for Central Sulawesi and the Maluku islands, where increased levels of conflict in 2001 were followed by the Malino peace agreements signed in December 2001 and February 2002, respectively. Second, current economic growth seems an only minor determinant of the scale of violence in these in most cases lingering conflicts. High levels of violence in Aceh between 1999 and 2002 were rather driven by a brutalization of the conflict, aimed at influencing the outcomes of the negotiations on autonomy. Intensified clashes between the Indonesian military and the GAM were increasingly accompanied by atrocities against civilians. Similarly, provocations by the military and the massive arrival of non-local Laskar Jihad fighters fueled the intensification of the conflicts in the Maluku islands and Central Sulawesi.

While being aware of potential distortions due to reverse causality and not claiming conflict to be exogenous to growth, we believe that causation in this setting strongly runs from conflict to growth, rather than the opposite way. The estimates from the fixed effects regressions are therefore assumed to reflect the growth impact of violent conflict rather accurately.

\section{Regression Results}

Table 4 presents the FE regression results for the main sectors. The dependent variable is the annual growth rate of district GDP. We run separate regressions for agriculture, industry, service, and total GDP growth. Some of the control variables are hardly significant, such as population growth, ethnic diversity, and the proxy for infrastructural development (availability of electricity). A short survey period, the inclusion of district fixed effects, and the relative invariability of the variables in the short run are most likely explanations. A significantly positive impact on industry and overall growth is found for average educational attainment of village heads, which is supposed to measure improvements in the quality of institutions. Two indicators of natural disasters are included. While the incidence of any kind 
of disaster (earthquake, landslide, and flood) in the years prior to the survey has no significant effect, ${ }^{11}$ the impact of the 2004 tsunami on subsequent economic growth in the affected regions is substantially negative, and particularly so for agriculture. No spillover effects from current and recent economic growth in a district's vicinity are found, and time dummies confirm overall higher economic growth in 2005 and 2008, as compared to 2002.

We include three indicators of violent conflict: the amount of material damage relative to total district GDP, the number of fatalities relative to district population size, and an indicator of conflict intensity in neighboring districts. ${ }^{12}$ Results indicate a substantial and significantly negative impact of conflict-related physical destruction on industry, service, and total growth. Under the assumption of unbiased estimates, this would translate into an approximate 11 percentage point decrease in industrial growth, and a 5 percentage point decrease in service sector growth for the two most affected districts of Aceh Timur and Poso (Central Sulawesi). A district affected by the average 2002 conflict intensity would accordingly expect a decrease in growth by 0.2 (industry) and 0.1 (services) percentage points, respectively.

The conflict coefficients for agriculture are small in magnitude and insignificant, which seems to confirm the primary sector's relative invulnerability to violent conflict. So far, we do not find any spillover effects from conflicts in neighboring districts on domestic growth. Likewise, the coefficients for conflict fatalities are hardly significant, with the marginal exception of the service sector. Keeping potential multicollinearity among the conflict variables in mind, ${ }^{13}$ this points to a more detrimental economic impact of physical destruction, as compared to human losses. Before having a closer look at such differing effects of different forms of violence, we investigate the particular economic effects of violent conflict in more detail, and turn to the sub-sector regression results.

Table 5 presents similar growth regressions for the, in total, eight sub-categories of the industry and service sectors. The agricultural sector is omitted here, as no further disaggregation is available. While the same set of control variables as before is used, we focus on the growth effects of conflict-related material damage and drop the simultaneous inclusion of the insignificant fatality indicator. Some of the before insignificant control variables now turn significant for specific branches, such as infrastructural development for finance,

\footnotetext{
${ }^{11}$ The lack of significance is likely to be caused by the long, three-year period under consideration, the relatively frequent occurrence of floods in Indonesia, and missing information on the scale of destruction.

${ }^{12}$ Here, the conflict spillover variable is based on relative material damage in neighboring districts. An indicator based on the number of fatalities is used in later regressions.

13 The Variance Inflation Factor (VIF), a simple measure to identify multicollinearity, is calculated and the results (VIF $<2$ for all explanatory variables) mitigate concerns of multicollinearity.
} 
transport and communication growth. Natural disasters particularly impact on the industrial sector, while services seem less severely affected. Neither economic growth nor conflicts in neighboring districts significantly influence domestic outcomes.

The conflict coefficients confirm our expectations and existing evidence from the literature. We find particularly strong negative conflict effects for financial services, transport/communication branches, and manufacturing industries. Substantial and significantly negative coefficients are also reported for construction industries and the commerce sector, which includes retail, hotels, and restaurants. Mining as well as the energy sector, i.e. electricity, gas, and water supply, appear unaffected. The only sub-category of the tertiary sector with a non-significant conflict coefficient is the area of services. The major share of this category constitutes of government expenditures for administration and defense, and maintained or increased security spending might be a potential driver behind this result. In a next step, alternative sub-samples and conflict coefficients are employed to test the robustness of the findings. As the regression set-up and the control variables remain unchanged, and for lack of space, we only present the estimates for the conflict coefficients. ${ }^{14}$ First, the sample is restricted to rural areas, where by far most of the violence took place. The results (Table 6a) are close to those for the whole sample: growth rates in the fields of finance, transport/communication, manufacturing and commerce are substantially affected by violent conflict; the negative impact on construction growth is marginally significant. In addition, we find negative conflict spillover effects on finance and transport/communication. While the transport sector relies almost by definition on cross-district activities, these results also suggest that trust and transactions in domestic financial markets are affected by neighboring conflicts.

Second, we exclude observations from the province of Aceh, to see whether our findings are entirely driven by the separatist conflict in this region (Table 6b). Again, the main results hold. Manufacturing and all sub-categories of the tertiary sector show significantly negative conflict coefficients. Here, marginal significance is also found for the agricultural sector. Negative conflict spillovers for transport/communication and finance are confirmed, and additionally found for the services sub-category. For the sake of completeness, we also run the regressions without the islands of Maluku and Sulawesi in order to exclude the associated ethno-communal conflicts. All main findings hold and actually turn out even stronger (results not reported).

\footnotetext{
${ }^{14}$ The full set of regression results is available from the authors upon request.
} 
Third, instead of conflict-related material damage, we use alternative indicators of conflict. The hardly significant impact of conflict fatalities is confirmed by the results in Table 6c. While we find similar directions of the growth effect for most sectors, results are less robust and marginally significant at best. A second alternative indicator of conflict is the share of villages in a district that report incidences of conflict. Almost consistently, the coefficients are highly insignificant (Table I.a in the Appendix). As this indicator does not take into account the severity of violence, the mere existence of conflict seems to have no a priori impact on the economy. Rather, the intensity of conflict matters. This is also confirmed by two further robustness checks: instead of relative indicators of physical destruction and human losses, we use absolute numbers of material damage and fatalities (Table I.b and I.c in the Appendix). The results are largely in line with the previous findings and underscore the particular conflict vulnerability of the service sector.

Finally, we exploit some of the growth dynamics of violent conflict. As the PODES data covers conflict in the respective previous year and is conducted three times per decade, the information on the occurrence of violent conflict is not continuous. While this prevents us from understanding the whole course of the conflict, village heads, however, do indicate whether conflict is solved or still ongoing. This information allows distinguishing between active conflicts and observations from an early post-conflict situation. Everything else equal, we split the indicators of relative conflict intensity accordingly. Table 7 presents the results, again confined to the estimates of the conflict coefficients.

Using the indicator of relative physical destruction for the whole sample (Table 7a), we find clear-cut differences between ongoing and solved conflicts. The estimated growth decline during ongoing conflicts is, for most sectors, considerably stronger than indicated by the singular indicator of conflict before. Transport/communication, construction, manufacturing, and commerce industries thereby seem to suffer most during episodes of violence. The estimates for the impact of solved conflicts are by far less substantial and significant. The only exception constitutes the services sub-category, possibly related to a cutback in public spending on security. A marginally negative impact of solved conflicts is still found for the financial sector and manufacturing, while the 'post-war' coefficients for construction and transport industries are insignificantly positive.

This positive trend especially for the construction sector is strengthened by the estimates for the sub-sample of rural districts (Table $7 \mathrm{~b}$ ). The main findings remain unchanged. Table $7 \mathrm{c}$ presents results for the indicators of conflict fatalities. Interestingly enough, the distinction between ongoing and solved conflicts reveal substantial and significant effects of human 
losses for active conflicts. According to the estimates and in line with previous findings from the indicators of material damage, finance, transport, construction, and manufacturing are affected in the most negative way. The results for solved conflicts also confirm the impression of distinctively different economic impacts at different stages of violent conflict.

\section{CONCLUSION}

The overall negative effect of violent conflict on economic outcomes has been confirmed by a growing amount of literature. However, relatively little is known on sector-specific impacts of violence, as disaggregated GDP data is hardly available from conflict-ridden countries. This study builds on detailed, district-level GDP data from Indonesia and on nation-wide, repeated data on the occurrence of conflicts. The panel analysis reveals significantly different effects of violent conflicts across sectors. As supposed by Collier (1999), industries dependent on either capital or transaction are most vulnerable to conflict. In particular, this includes manufacturing, finance, transport and communication, as well as retail and the gastronomy. The construction sector suffers substantially during active conflicts, while a slightly positive trend is found in the early post-conflict period. Other sectors' recovery appears less rapid; especially manufacturing industries and the finance sector seem more reliant on a lasting peace. Spillover effects from conflicts in neighboring regions are not obvious, with the exception of the areas of finance, transport and communication.

Results also show that the intensity especially of physical destruction matters most for economic growth, as opposed to the mere existence of low-intensity conflicts. As we do not control for saving rates, reduced investment is another potential driver of the economic downturn in times of conflict. Overall, the analysis points to only temporary, short-run impacts of violent conflict on economic growth. A limitation of this study is the intermittent character of the conflict data. As we cannot observe conflict before and after the respective survey years, this prevents us from a more detailed analysis of the growth dynamics during conflict and in post-conflict times. Still, the findings point to substantial differences in the sector-specific impacts of violent conflict, with potentially important implications for the reconstruction process and future development. 


\section{REFERENCES}

Abadie A. and J. Gardeazabal (2003), 'The Economic Costs of Conflict: A Case Study of the Basque Country', American Economic Review, 93 (1), 113-132.

Acemoglu D., S. Johnson, and J. Robinson (2004), 'Institutions as the Fundamental Cause of Long-Run Growth', in P. Aghion and S. Durlauf (Eds.), Handbook of Economic Growth, Amsterdam.

Acemoglu D., S. Johnson, and J. Robinson (2001), 'Colonial Origins of Comparative Development: An Empirical Investigation', American Economic Review, 91, 1369401.

Alesina A., R. Baqir, and W. Easterly (1999), 'Public Goods and Ethnic Divisions', Quarterly Journal of Economics, 114, 1243-84.

Arunatilake N., S. Jayasuriya and S. Kelegama (2001), 'The Economic Cost of the War in Sri Lanka', World Development, 29 (9), 1483-1500.

Barro R.J. and R.M. McCleary (2003), 'Religion and Economic Growth', American Sociological Review, 68 (5), 760-81.

Barron P., K. Kaiser, and M. Pradhan (2009), 'Understanding Variations in Local Conflict: Evidence and Implications from Indonesia', World Development, 37 (3), 698-713.

Barron P., K. Kaiser, and M. Pradhan (2004), 'Local Conflict in Indonesia: Measuring Incidence and Identifying Patterns', World Bank Policy Research Working Paper 3384.

Barron P. and J. Sharpe (2008), ,Local conflict in post-Suharto Indonesia: Understanding variations in violence levels and forms through local newspapers', Journal of East Asian Studies, 8, 395-424.

Blattman C. and E. Miguel (2009), 'Civil War', NBER Working Paper 14801, forthcoming in the Journal of Economic Literature.

Blomberg S.B. and G.D. Hess (2006), 'How Much Does Violence Tax Trade?', The Review of Economics and Statistics, 88 (4), 599-612.

Bodea C. and I.A. Elbadawi (2008), 'Political Violence and Economic Growth', Policy Research Working Paper 4692, The World Bank.

Bos J.W.B., C. Economidou, M. Koetter, and J.W. Kolari (2010), 'Do All Countries Grow Alike?', Journal of Development Economics, 91, 113-127.

Bosworth B.P. and S.M. Collins (2003), 'The Empirics of Growth: An Update', Brookings Papers on Economic Activity, 2, 113-206.

Bozzoli, C., T. Brück, T. Drautzburg, S. Sottsas (2008), 'Economic Costs of Mass Violent Conflict', Politikberatung kompakt, 42, DIW Berlin.

Brown, G., C. Wilson, and S. Hadi (2005), 'Overcoming Violent Conflict: Peace and Development Analysis in Maluku and North Maluku', CPRU-UNDP, LIPI and BAPPENAS.

Brück T. (1997), 'Macroeconomic Effects of the War in Mozambique', Queen Elizabeth House Working Paper Series 11, University of Oxford International Development Centre. 
Cerra V. and S.C. Saxena (2008), 'Growth Dynamics: The Myth of Economic Recovery', American Economic Review, 98 (1), 439-57.

Collier P. (1999). 'On the Economic Consequences of Civil War', Oxford Economic Papers, $51,168-83$.

Collier P. and A. Hoeffler (2007), 'Civil War', in K. Hartley and T. Sandler (Eds.), Handbook of Defense Economics, Elsevier North Holland.

Collier, P. and A. Hoeffler (2004), 'Greed and Grievance in CivilWar', Oxford Economic Papers, 56 (4), 563-95.

Collier P. (2009), 'Post-conflict Recovery: How Should Strategies Be Distinctive?', Journal of African Economies, 18, AERC Supplement 1, 99-131.

Deininger K. (2003) 'Causes and Consequences of Civil Strife: Micro-Level Evidence from Uganda', Oxford Economic Papers, 55, 579-606.

De Groot O. (2010), 'The Spill-Over Effects of Violent Conflict on Economic Growth in Neighboring Countries in Africa', forthcoming in Defence and Peace Economics.

Depetris Chauvin, N.M. (2009), 'The Effects of Conflict on the Structure of the Economy', Oxford Centre for the Analysis of Resource Rich Economies.

Durlauf S.N., P. Johnson, and J. Temple (2005), 'Growth Econometrics', in P. Aghion and S.N. Durlauf (Eds.), Handbook of Economic Growth, Amsterdam.

Easterly W. and R. Levine (2001), 'It's Not Factor Accumulation: Stylized Facts and Growth Models', World Bank Economic Review, 15 (2), 177-219.

Esfahani H.S. and M.T. Ramírez (2003), 'Institutions, Infrastructure, and Economic Growth', Journal of Development Economics, 70, 443-77.

FAO (1997), 'FAO/WFP Crop and Food Supply Assessment Mission to Rwanda 1 July 1997, Special Reports and Alerts (GIEWS)'.

Fearon, J.D. and D.D. Laitin. (2003), 'Ethnicity, Insurgency, and Civil War', American Political Science Review, 97, 75-90.

Fielding D. (2004), 'How Does Violent Conflict Affect Investment Location Decisions? Evidence from Israel during the Intifada', Journal of Peace Research, 41 (4), 465-84.

Fielding D. (2000), 'Counting the Cost of the Intifada: Consumption, Saving and Political Instability in Israel', Discussion Paper in Economics 00/8', University of Leicester.

Frankel J. and D. Romer (1999), 'Does Trade Cause Growth?', American Economic Review, 89 (3), 379-99.

Garcia J.G. and L. Soelistianingsih (1998), 'Why Do Differences in Provincial Incomes Persist in Indonesia?', Bulletin of Indonesian Economic Studies, 34 (1), 95-120.

Ghobarah H.A., P. Huth and B. Russett (2003), 'Civil Wars Kill and Maim People - Long After the Shooting Stops', American Political Science Review, 97(2), 189-202.

Glick R. and A.M. Taylor (2005), 'Collateral Damage: Trade Disruption and the Economic Impact of War', CEPR Discussion Paper No. 5209.

Gupta S., B. Clements, R. Bhattacharya, and S. Chakravarti (2004), 'Fiscal Consequences of Armed Conflict and Terrorism in Low- and Middle-Income Countries', European Journal of Political Economy, 20, 403-421. 
Human Rights Watch (2002), 'Breakdown: Four Years of Communal Violence in Central Sulawesi', C1409, New York.

Imai K. and J. Weinstein (2000), 'Measuring the Economic Impact of Civil War', CID Working Paper 51, Harvard University.

Jensen P.S. and K.S. Gleditsch (2009), 'Rain, Growth, and Civil War: The Importance of Location', Defense and Peace Economics, 20 (5), 359-72.

Kang, S. and J. Meernik (2005), 'Civil War Destruction and the Prospects for Economic Growth', Journal of Politics, 67 (1), 88-109.

Knight M., N. Loayza, and D. Villanueva (1996), 'The Peace Dividend: Military Spending Cuts and Economic Growth', World Bank Policy Research Working Paper 1577.

Koubi V. (2005), 'War and Economic Performance', Journal of Peace Research, 42 (1), 6782.

Lai B. and C. Thyne (2007), 'The Effects of Civil War on Education 1980-97', Journal of Peace Research, 44 (3), 277-92.

Lopez H. and Q. Wodon (2005), 'The Economic Impact of Armed Conflict in Rwanda', Journal of African Economies, 14 (4), 586-602.

Masters W. and M. McMillan (2001), 'Climate and Scale in Economic Growth', Journal of Economic Growth, 6 (3), 167-86.

Mawardi S. (2006), 'Community Synthesis Report: Kampung Pisang, Ternate, North Maluku, Indonesia', The SMERU Research Institute, Jakarta.

McCulloch N. and B.S. Sjahrir (2008), 'Endowments, Location or Luck? Evaluating the Determinants of Sub-National Growth in Decentralized Indonesia', Policy Research Working Paper 4769, The World Bank.

Miguel E., S. Satyantah, and E. Sergenti (2004), 'Economic Shocks and Civil Conflict: An Instrumental Variables Approach'; Journal of Political Economy, 112 (4), 725-753.

Murdoch J.C. and T. Sandler (2002), 'Economic Growth, Civil Wars, and Spatial Spillovers', Journal of Conflict Resolution, 46 (1), 91-110.

Neumayer E. (2004), 'The Impact of Political Violence on Tourism: Dynamic Cross-National Estimation', Journal of Conflict Resolution, 48 (2), 259-281.

Organski A.F.K. and J. Kugler (1980), The War Ledger, University of Chicago Press.

Psacharapoulos G. and H.A. Patrinos (2004), 'Returns to Investments in Education: A Further Update', Education Economics, 12 (2), 111-34.

Rao B.B. and A. Corray (2009), 'How Useful is Growth Literature for Policies in the Developing Countries?', MPRA Paper No. 14573.

Reid, A. (Ed.) (2006), 'Verandah of Violence: The Background to the Aceh Problem', Singapore University Press.

Ross M.L. (2004), 'What Do We Know About Natural Resources and Civil War?', Journal of Peace Research, 41 (3), 337-56.

Solow R.M. (1956), 'A Contribution to the Theory of Economic Growth', Quarterly Journal of Economics, 70, 65-94.

Svensson J. (1998), 'Investment, Property Rights and Political Stability: Theory and Evidence', European Economic Review, 42, 1317-41. 
Verpoorten M. (2009) 'Household Coping in War- and Peacetime: Cattle Sales in Rwanda, 1991-2001', Journal of Development Economics, 88, 67-86.

Tadjoeddin M.Z. and M.M. Murshed (2007), 'Socio-Economic Determinants of Everyday Violence in Indonesia: An Empirical Investigation of Javenese Districts, 1994-2003'; Journal of Peace Research, 44 (6), 689-709.

Teodosijević, S.B. (2003), ‘Armed Conflicts and Food Security’, ESA Working Paper No. 0311.

Varshney A., P. Barron, S. Jaffrey, B. Palmer, and I. Rasyid (2009), 'Conflict After the Big Wave: Early Evidence from Maluku and North Maluku', Presentation at the World Bank, Jakarta, $12^{\text {th }}$ August 2009. 


\begin{tabular}{|c|c|c|c|c|c|c|}
\hline & Variable & $\mathbf{n}$ & Mean & Std. Dev. & Min & Max \\
\hline \multirow{16}{*}{\begin{tabular}{l|} 
\\
\\
0 \\
0 \\
0 \\
0 \\
0 \\
0 \\
0 \\
0 \\
0 \\
0 \\
0 \\
0 \\
0 \\
0
\end{tabular}} & District GDP growth: Agriculture & 1120 & 3.45 & 4.55 & -40.49 & 37.33 \\
\hline & District GDP growth: Mining & 1036 & 4.76 & 8.10 & -48.49 & 48.32 \\
\hline & District GDP growth: Manufacturing & 1118 & 4.42 & 5.09 & -48.62 & 48.36 \\
\hline & District GDP growth: Energy & 1115 & 6.70 & 7.32 & -48.48 & 47.70 \\
\hline & District GDP growth: Construction & 1115 & 6.69 & 6.55 & -40.68 & 47.95 \\
\hline & District GDP growth: Industry & 1123 & 4.78 & 5.21 & -37.51 & 42.39 \\
\hline & District GDP growth: Commerce & 1121 & 6.04 & 4.57 & -43.13 & 43.54 \\
\hline & District GDP growth: Transport and Communication & 1117 & 6.85 & 5.10 & -27.69 & 46.59 \\
\hline & District GDP growth: Finance & 1104 & 6.86 & 6.80 & -40.48 & 46.72 \\
\hline & District GDP growth: Services (sub-category) & 1110 & 5.66 & 4.85 & -49.33 & 45.22 \\
\hline & District GDP growth: Services & 1123 & 6.06 & 3.69 & -41.56 & 34.81 \\
\hline & District GDP growth: Total & 1123 & 4.75 & 3.45 & -33.57 & 35.91 \\
\hline & Spillovers: weighted ${ }^{*}$ average agricultural growth & 1123 & 3.65 & 2.20 & -14.95 & 11.13 \\
\hline & Spillovers: weighted average industrial growth & 1123 & 4.13 & 4.30 & -31.47 & 31.57 \\
\hline & Spillovers: weighted average service sector growth & 1123 & 5.84 & 2.68 & -21.43 & 17.95 \\
\hline & Spillovers: weighted average total GDP growth & 1123 & 4.23 & 2.74 & -26.23 & 21.97 \\
\hline \multirow{6}{*}{$\begin{array}{l}2 \\
\vdots \\
\vdots \\
0 \\
0 \\
0 \\
0\end{array}$} & Share of villages where electricity is available & 1123 & 94.78 & 13.07 & 0.74 & 100 \\
\hline & Average level of education of village heads (1-6) & 1123 & 4.30 & 0.71 & 1.45 & 6 \\
\hline & Population growth rate & 1123 & 2.00 & 2.32 & -4.83 & 14.77 \\
\hline & Share of villages with more than one ethnicity & 1123 & 72.74 & 23.39 & 2.42 & 100 \\
\hline & Natural disaster in the last three years & 1123 & 0.376 & 0.238 & 0 & 1 \\
\hline & Tsunami: number of new houses required (per $1.000 \mathrm{Inh})$. & 1123 & 0.046 & 0.614 & 0 & 13.66 \\
\hline \multirow{8}{*}{ 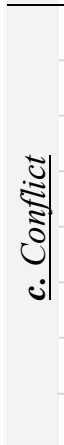 } & Share of villages affected by conflict & 1123 & 0.044 & 0.062 & 0 & 0.72 \\
\hline & Share of villages affected by violent conflict & 1123 & 0.029 & 0.040 & 0 & 0.38 \\
\hline & Fatalities per 1.000 inhabitants & 1123 & 0.015 & 0.138 & 0 & 2.86 \\
\hline & Material damage as $.01 \%$-share of GDP & 1123 & 0.050 & 0.342 & 0 & 6.98 \\
\hline & Material damage as $.01 \%$-share of GDP (solved conflicts) & 1123 & 0.031 & 0.201 & 0 & 5.19 \\
\hline & Material damage as .01 \%-share of GDP (ongoing conflicts) & 1123 & 0.019 & 0.225 & 0 & 6.64 \\
\hline & Spillovers: fatalities per 1.000 inhabitants & 1123 & 0.017 & 0.109 & 0 & 1.97 \\
\hline & Spillovers: material damage as $.01 \%$-share of GDP & 1123 & 0.041 & 0.224 & 0 & 4.93 \\
\hline
\end{tabular}

${ }^{*}$ The average neighboring growth rate $n g$ for sector $s$ in district $i$ is equal to the sum of the growth rates $g_{n, s}$ in the neighboring districts $\mathrm{n}=1, \ldots, \mathrm{m}_{\mathrm{i}}$, weighted by the neighbor's economic size $G D P_{n, s}$ relative to the economic size of all the $m_{i}$ surrounding districts:

$$
n g_{i, s}=\sum_{n=1}^{m_{i}}\left(g_{n, s} \times \frac{G D P_{n, s}}{\sum_{n=1}^{m_{i}} G D P_{n, s}}\right)
$$


Table 2: Violent Conflict - Descriptive Statistics

\begin{tabular}{l|c|c|c}
\hline \multicolumn{1}{c|}{ Conflict Indices } & $\mathbf{2 0 0 2}$ & $\mathbf{2 0 0 5}$ & $\mathbf{2 0 0 8}$ \\
\hline \hline \multicolumn{2}{|c|}{ Total } \\
\hline Share of villages affected by conflict (\%) & 7.2 & 2.7 & 3.2 \\
\hline Share of villages affected by violent conflict (\%) & 4.4 & 2.1 & 2.3 \\
\hline Number of fatalities & 4,858 & 276 & 335 \\
\hline Material damage (million of Rupiah) & 740,560 & 97,742 & 8,476 \\
\hline \hline \multicolumn{2}{|c|}{ District Means } & & \\
\hline Number of fatalities & 13.0 & 0.7 & 0.9 \\
\hline Material damage (million of Rupiah) & 2,054 & 260 & 23 \\
\hline Fatalities per 1.000 inhabitants & 0.042 & 0.002 & 0.002 \\
\hline Material damage as .01 \%-share of GDP & 0.132 & 0.016 & 0.002 \\
\hline - Vion con
\end{tabular}

-Violent conflict is defined as conflict that involves either human or physical losses.

Table 3: Districts most affected by violence

\begin{tabular}{|c|c|c|c|c|c|c|c|}
\hline (A) & Province & District & $\begin{array}{c}\text { Fatalities } \\
\text { per Capita }\end{array}$ & (B) & Province & District & $\begin{array}{l}\text { Mat. Damage } \\
\text { (Share GDP) }\end{array}$ \\
\hline (1) & NAD & Aceh Timur & 2.86 & (1) & NAD & Aceh Timur & 6.98 \\
\hline (9) & NAD & Aceh Tengah & 2.08 & (4) & Sulawesi Tengah & Poso & 6.65 \\
\hline (23) & Maluku Utara & Halmahera Barat & 1.97 & $(16)$ & Maluku & Pulau Buru & 3.99 \\
\hline (2) & Sulawesi Tengah & Poso & 1.39 & $(66)$ & Sumatera Barat & Kepulauan Mentawai & 2.65 \\
\hline (93) & Maluku & Kota Ambon & 1.24 & (11) & NAD & Kota_a_angs $\underline{\text { a }}$ & 1.51 \\
\hline (73) & NAD & Aceh Selatan & 0.77 & (194) & Jambi & Kerinci & 1.48 \\
\hline$(16)^{-}$ & NAD & Aceh Barat Daya & 0.63 & $(43)$ & Sulawesi Selatan & Mamuju & 1.25 \\
\hline (218) & NAD & Aceh Besar & 0.34 & (178) & Jambi & Merangin & 1.24 \\
\hline (13) & NTT & Rote Ndao & 0.30 & (2) & NAD & Aceh Tengah & 1.21 \\
\hline$(97)$ & NAD & Aceh Utara & 0.26 & (29) & NTB & Dompu & 1.13 \\
\hline (5) & NAD & Kota Langsa & 0.25 & $(40)$ & Maluku & Maluku Tenggara & 1.07 \\
\hline$(468)$ & NAD & Nagan Raya & 0.22 & (303) & Sulawesi Selatan & Kota Palopo & 1.07 \\
\hline (468) & NAD & Aceh Barat & 0.20 & (9) & NTT & Rote Ndao & 1.02 \\
\hline$(49)$ & Kalimantan Tengah & Kotawaringin Barat & 0.18 & (303) & Jambi & Bungo & 1.01 \\
\hline$(468)$ & Papua & Puncak Jaya & 0.17 & $(21)$ & NAD & Pidie & 1.01 \\
\hline (3) & Maluku & Pulau Buru & 0.17 & (7) & NAD & Aceh Barat Daya & 1.00 \\
\hline (33) & Maluku & Maluku Tengah & 0.16 & $(83)$ & Maluku & Maluku Tengah' & 0.96 \\
\hline (207) & NAD & Kota_L_hoksseumawawe & 0.15 & $(22)$ & Sulawesi Selatan & Luwu & 0.88 \\
\hline$(82)$ & NAD & Bireuen & 0.13 & $(56)$ & NAD & Aceh Tamiang & 0.84 \\
\hline$(105)$ & NAD & Aceh Singkil & 0.12 & (257) & NTB & Lombok Tengah & 0.81 \\
\hline
\end{tabular}

Fatalities: conflict-related fatalities per 1.000 inhabitants. Material damage as .01\%-Share of Total District GDP.

Observations from 2005. Urban_districts__ _n italic. In parentheses: rank of the district in terms of mat. damage (A) and fatalities (B), respectively. 
Figure 1: Growth Trends 2001 - 2008

\section{Growth (Total)}

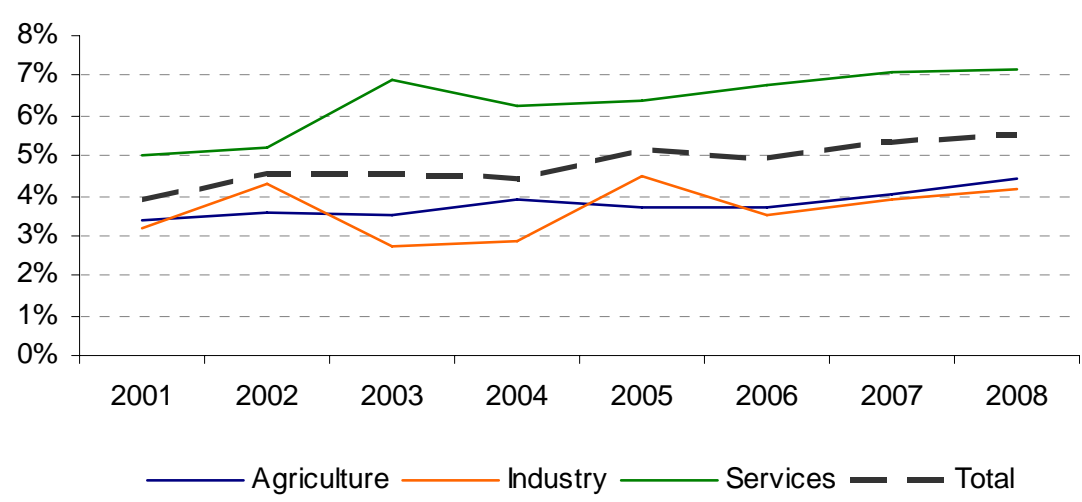

Figure 2: Distribution of Violence in 2002

a) Fatalities per Capita

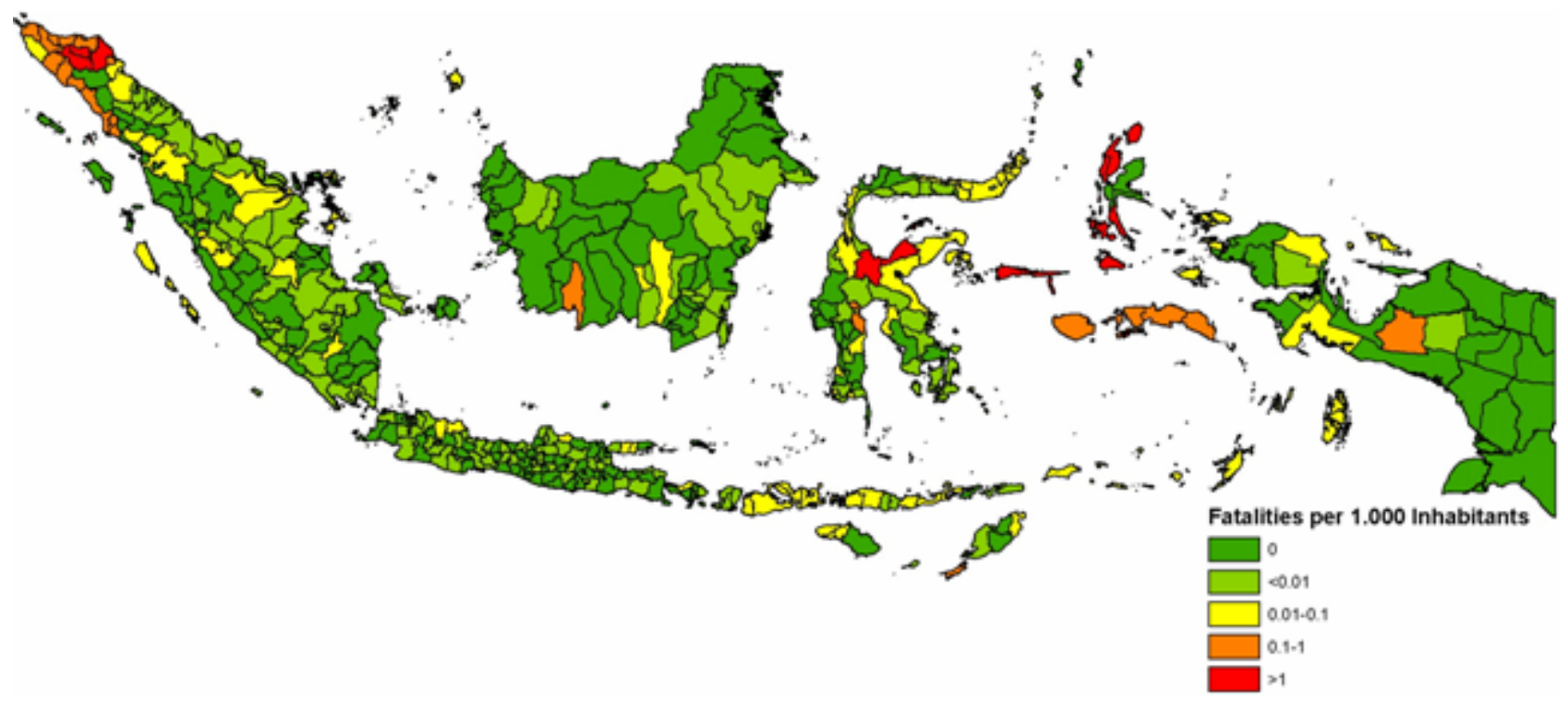

b) Material Damage (as Share of Total District GDP)

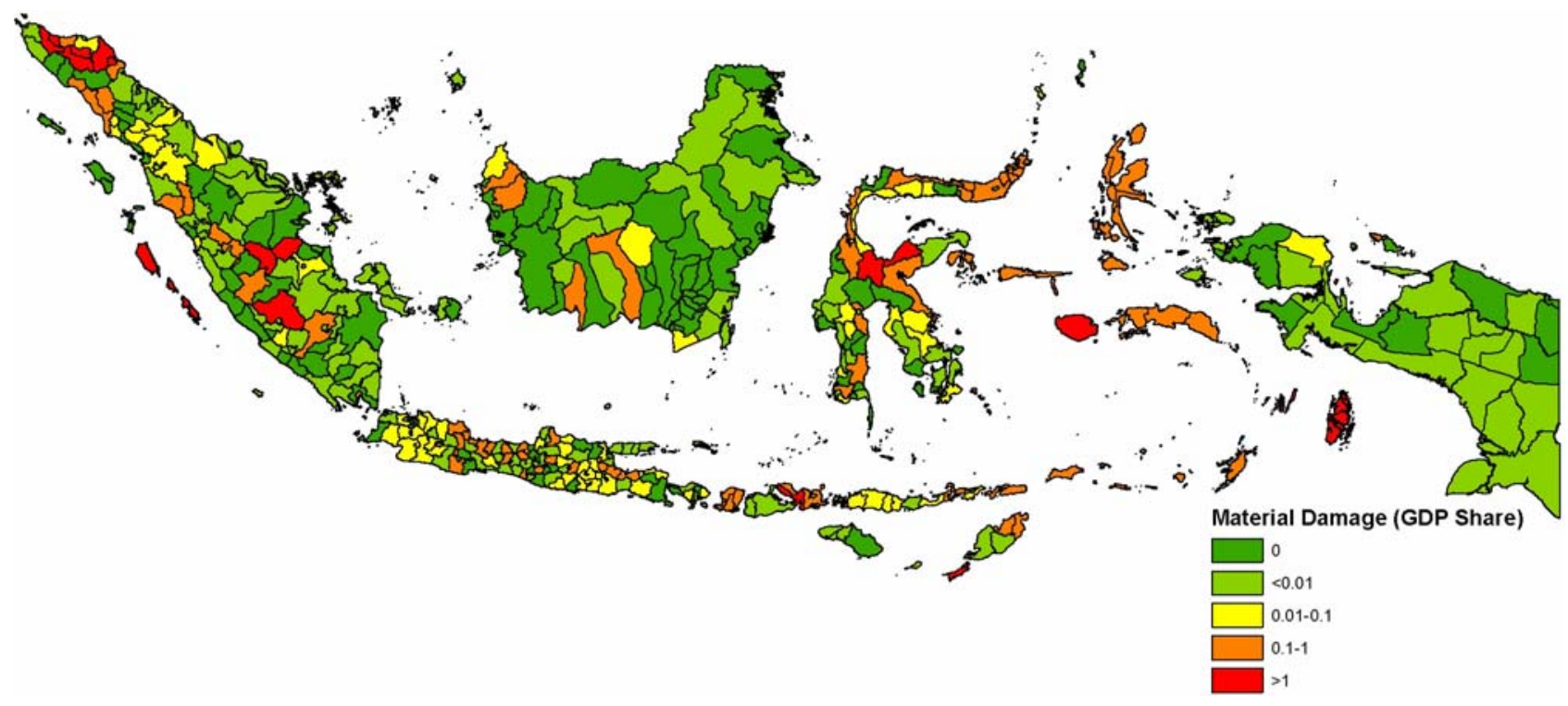


Table 4: Base FE Regression Results

\begin{tabular}{|c|c|c|c|c|}
\hline \multirow{2}{*}{$\begin{array}{l}\text { Dependent Variable: } \\
\text { GDP Growth }\end{array}$} & (1) & (2) & (3) & (4) \\
\hline & Agricult. & Industry & Services & Total \\
\hline Population Growth Rate & $\begin{array}{c}0.06 \\
(0.08)\end{array}$ & $\begin{array}{c}0.01 \\
(0.09)\end{array}$ & $\begin{array}{l}-0.05 \\
(0.06)\end{array}$ & $\begin{array}{l}-0.08 \\
(0.07)\end{array}$ \\
\hline Availability of Electricity & $\begin{array}{l}-0.05 \\
(0.05)\end{array}$ & $\begin{array}{c}0.11 \\
(0.07)\end{array}$ & $\begin{array}{c}0.08 \\
(0.05)\end{array}$ & $\begin{array}{c}0.05 \\
(0.05)\end{array}$ \\
\hline Av. Education of Village Heads & $\begin{array}{c}0.84 \\
(0.69)\end{array}$ & $\begin{array}{l}1.45^{* *} \\
(0.59)\end{array}$ & $\begin{array}{l}-0.06 \\
(0.35)\end{array}$ & $\begin{array}{c}0.84 * * \\
(0.36)\end{array}$ \\
\hline Ethnic Diversity & $\begin{array}{l}0.03 * \\
(0.01)\end{array}$ & $\begin{array}{c}0.01 \\
(0.02)\end{array}$ & $\begin{array}{c}0.00 \\
(0.01)\end{array}$ & $\begin{array}{c}0.01 \\
(0.01)\end{array}$ \\
\hline Natural Disaster Occurred & $\begin{array}{c}0.83 \\
(0.65)\end{array}$ & $\begin{array}{l}-0.68 \\
(0.86)\end{array}$ & $\begin{array}{l}-0.21 \\
(0.64)\end{array}$ & $\begin{array}{c}0.32 \\
(0.44)\end{array}$ \\
\hline Tsunami: Physical Destruction & $\begin{array}{c}-2.94 * * * \\
(0.58)\end{array}$ & $\begin{array}{l}-1.45^{*} \\
(0.75)\end{array}$ & $\begin{array}{l}-0.61 \\
(0.48)\end{array}$ & $\begin{array}{c}-1.52 * * * \\
(0.47)\end{array}$ \\
\hline $\begin{array}{l}\text { Conflict: Material Damage } \\
(\% \text { GDP) }\end{array}$ & $\begin{array}{l}-0.17 \\
(0.42)\end{array}$ & $\begin{array}{c}-1.62 * * \\
(0.75)\end{array}$ & $\begin{array}{c}-0.70^{* *} \\
(0.31)\end{array}$ & $\begin{array}{c}-0.84^{* *} \\
(0.35)\end{array}$ \\
\hline Conflict: Fatalities per Capita & $\begin{array}{c}0.03 \\
(0.87)\end{array}$ & $\begin{array}{c}0.26 \\
(1.59)\end{array}$ & $\begin{array}{l}-1.23 \\
(0.98)\end{array}$ & $\begin{array}{l}-0.91 \\
(0.83)\end{array}$ \\
\hline $\begin{array}{l}\text { Spillover: Conflict in } \\
\text { Neighboring Districts }\end{array}$ & $\begin{array}{l}-0.71 \\
(0.62)\end{array}$ & $\begin{array}{c}0.72 \\
(0.87)\end{array}$ & $\begin{array}{c}0.06 \\
(0.76)\end{array}$ & $\begin{array}{c}0.33 \\
(0.42)\end{array}$ \\
\hline $\begin{array}{l}\text { Average Neighboring Growth: } \\
\text { Total GDP }\end{array}$ & $\begin{array}{l}-0.09 \\
(0.08)\end{array}$ & $\begin{array}{l}-0.08 \\
(0.14)\end{array}$ & $\begin{array}{l}-0.03 \\
(0.06)\end{array}$ & $\begin{array}{c}0.02 \\
(0.11)\end{array}$ \\
\hline Time Dummy: Year 2005 & $\begin{array}{c}0.29 \\
(0.45)\end{array}$ & $\begin{array}{c}1.45^{* * *} \\
(0.33)\end{array}$ & $\begin{array}{c}0.99 * * * \\
(0.29)\end{array}$ & $\begin{array}{c}1.05 * * * \\
(0.21)\end{array}$ \\
\hline Time Dummy: Year 2008 & $\begin{array}{c}0.61 \\
(0.41)\end{array}$ & $\begin{array}{c}1.52^{* * *} \\
(0.43)\end{array}$ & $\begin{array}{c}1.63 * * * \\
(0.30)\end{array}$ & $\begin{array}{c}1.15^{* * *} \\
(0.23)\end{array}$ \\
\hline Constant & $\begin{array}{c}2.66 \\
(6.11) \\
\end{array}$ & $\begin{array}{c}-13.09^{*} \\
(7.83) \\
\end{array}$ & $\begin{array}{l}-2.11 \\
(5.71) \\
\end{array}$ & $\begin{array}{l}-5.03 \\
(4.83) \\
\end{array}$ \\
\hline Observations & 1120 & 1123 & 1123 & 1123 \\
\hline R-squared & 0.19 & 0.10 & 0.11 & 0.17 \\
\hline No. of Groups & 375 & 375 & 375 & 375 \\
\hline Av. Obs. per Group & 2.99 & 2.99 & 2.99 & 2.99 \\
\hline
\end{tabular}

Robust standard errors in parentheses. * significant at $10 \%$; * significant at $5 \%$; *** significant at $1 \%$. Conflict Indices: Fatalities per 1.000 Inhabitants. Material Damage as $0.01 \%$-Points of Total District GDP 
Table 5: Regressions for Sub-sectors

\begin{tabular}{|c|c|c|c|c|c|c|c|c|}
\hline \multirow{3}{*}{$\begin{array}{l}\text { Dependent Variable: } \\
\text { GDP Growth }\end{array}$} & (5) & (6) & (7) & (8) & (9) & (10) & (11) & (12) \\
\hline & \multicolumn{4}{|c|}{ Industry } & \multicolumn{4}{|c|}{ Services } \\
\hline & Mining & Manufact. & Energy & Construct. & Commerce & Transport & Finance & Services \\
\hline Population Growth Rate & $\begin{array}{c}0.00 \\
(0.15)\end{array}$ & $\begin{array}{c}0.08 \\
(0.06)\end{array}$ & $\begin{array}{l}-0.01 \\
(0.15)\end{array}$ & $\begin{array}{c}0.13 \\
(0.13)\end{array}$ & $\begin{array}{c}0.01 \\
(0.08)\end{array}$ & $\begin{array}{c}0.01 \\
(0.08)\end{array}$ & $\begin{array}{c}0.04 \\
(0.12)\end{array}$ & $\begin{array}{l}-0.07 \\
(0.09)\end{array}$ \\
\hline Availability of Electricity & $\begin{array}{l}0.17^{*} \\
(0.10)\end{array}$ & $\begin{array}{c}0.08 \\
(0.06)\end{array}$ & $\begin{array}{c}0.02 \\
(0.12)\end{array}$ & $\begin{array}{c}0.08 \\
(0.10)\end{array}$ & $\begin{array}{c}0.07 \\
(0.06)\end{array}$ & $\begin{array}{c}0.13 * * \\
(0.06)\end{array}$ & $\begin{array}{c}0.29 * * * \\
(0.09)\end{array}$ & $\begin{array}{c}0.01 \\
(0.06)\end{array}$ \\
\hline Av. Education of Village Heads & $\begin{array}{l}-0.29 \\
(1.10)\end{array}$ & $\begin{array}{c}1.46^{* * *} \\
(0.43)\end{array}$ & $\begin{array}{c}0.04 \\
(0.81)\end{array}$ & $\begin{array}{l}2.28 * * * \\
(0.75)\end{array}$ & $\begin{array}{c}0.43 \\
(0.50)\end{array}$ & $\begin{array}{l}-0.48 \\
(0.55)\end{array}$ & $\begin{array}{l}-0.40 \\
(1.10)\end{array}$ & $\begin{array}{l}-0.23 \\
(0.58)\end{array}$ \\
\hline Ethnic Diversity & $\begin{array}{c}0.01 \\
(0.03)\end{array}$ & $\begin{array}{l}-0.02 \\
(0.02)\end{array}$ & $\begin{array}{l}-0.06^{*} \\
(0.03)\end{array}$ & $\begin{array}{c}0.04 \\
(0.02)\end{array}$ & $\begin{array}{c}0.01 \\
(0.01)\end{array}$ & $\begin{array}{c}0.02 \\
(0.02)\end{array}$ & $\begin{array}{l}-0.01 \\
(0.03)\end{array}$ & $\begin{array}{l}-0.02 \\
(0.02)\end{array}$ \\
\hline Natural Disaster Occurred & $\begin{array}{c}0.28 \\
(1.86)\end{array}$ & $\begin{array}{c}-1.78 * * \\
(0.82)\end{array}$ & $\begin{array}{l}-0.01 \\
(1.46)\end{array}$ & $\begin{array}{l}-0.32 \\
(1.15)\end{array}$ & $\begin{array}{l}-0.73 \\
(0.77)\end{array}$ & $\begin{array}{c}1.81 \\
(1.14)\end{array}$ & $\begin{array}{c}0.82 \\
(1.56)\end{array}$ & $\begin{array}{l}-1.49 \\
(1.00)\end{array}$ \\
\hline Tsunami: Physical Destruction & $\begin{array}{l}-0.98 \\
(1.00)\end{array}$ & $\begin{array}{c}-2.02 * * * \\
(0.33)\end{array}$ & $\begin{array}{c}-1.09 * * * \\
(0.35)\end{array}$ & $\begin{array}{l}-1.30 \\
(0.94)\end{array}$ & $\begin{array}{l}-1.05^{*} \\
(0.56)\end{array}$ & $\begin{array}{l}-0.38 \\
(0.72)\end{array}$ & $\begin{array}{c}0.31 \\
(1.45)\end{array}$ & $\begin{array}{l}-0.54 \\
(0.62)\end{array}$ \\
\hline $\begin{array}{l}\text { Conflict: Material Damage } \\
(\% \text { GDP) }\end{array}$ & $\begin{array}{l}-0.28 \\
(0.41)\end{array}$ & $\begin{array}{c}-1.39 * * * \\
(0.48)\end{array}$ & $\begin{array}{l}-0.07 \\
(0.45)\end{array}$ & $\begin{array}{l}-1.08 * \\
(0.65)\end{array}$ & $\begin{array}{l}-0.85^{* *} \\
(0.39)\end{array}$ & $\begin{array}{l}-1.50^{* *} \\
(0.69)\end{array}$ & $\begin{array}{c}-1.63 * * \\
(0.66)\end{array}$ & $\begin{array}{l}-0.34 \\
(0.30)\end{array}$ \\
\hline $\begin{array}{l}\text { Spillover: Conflict in } \\
\text { Neighboring Districts }\end{array}$ & $\begin{array}{l}-0.59 \\
(0.59)\end{array}$ & $\begin{array}{c}0.89 \\
(0.97)\end{array}$ & $\begin{array}{l}-0.84 \\
(0.85)\end{array}$ & $\begin{array}{c}1.07 \\
(1.33)\end{array}$ & $\begin{array}{l}-0.47 \\
(0.86)\end{array}$ & $\begin{array}{l}-1.30 \\
(0.95)\end{array}$ & $\begin{array}{c}1.11 \\
(2.20)\end{array}$ & $\begin{array}{c}0.44 \\
(1.26)\end{array}$ \\
\hline $\begin{array}{l}\text { Average Neighboring Growth: } \\
\text { Total GDP }\end{array}$ & $\begin{array}{l}-0.23 \\
(0.14)\end{array}$ & $\begin{array}{c}0.02 \\
(0.14)\end{array}$ & $\begin{array}{c}0.04 \\
(0.15)\end{array}$ & $\begin{array}{l}-0.15 \\
(0.14)\end{array}$ & $\begin{array}{l}-0.06 \\
(0.08)\end{array}$ & $\begin{array}{l}-0.06 \\
(0.07)\end{array}$ & $\begin{array}{l}-0.03 \\
(0.16)\end{array}$ & $\begin{array}{c}0.05 \\
(0.07)\end{array}$ \\
\hline Time Dummy: Year 2005 & $\begin{array}{c}1.01 \\
(0.72)\end{array}$ & $\begin{array}{c}1.14 * * * \\
(0.29)\end{array}$ & $\begin{array}{l}-1.07 * \\
(0.59)\end{array}$ & $\begin{array}{c}1.38^{* * *} \\
(0.45)\end{array}$ & $\begin{array}{c}1.64 * * * \\
(0.37)\end{array}$ & $\begin{array}{l}-0.16 \\
(0.39)\end{array}$ & $\begin{array}{c}0.13 \\
(0.79)\end{array}$ & $\begin{array}{c}0.54 \\
(0.48)\end{array}$ \\
\hline Time Dummy: Year 2008 & $\begin{array}{c}1.01 \\
(0.79)\end{array}$ & $\begin{array}{c}1.63^{* * *} \\
(0.43)\end{array}$ & $\begin{array}{l}-1.05 \\
(0.70)\end{array}$ & $\begin{array}{c}1.74 * * * \\
(0.60)\end{array}$ & $\begin{array}{c}1.84 * * * \\
(0.42)\end{array}$ & $\begin{array}{c}0.71 \\
(0.47)\end{array}$ & $\begin{array}{c}1.86^{* * *} \\
(0.66)\end{array}$ & $\begin{array}{c}1.71^{* * *} \\
(0.50)\end{array}$ \\
\hline Constant & $\begin{array}{l}-10.48 \\
(11.24)\end{array}$ & $\begin{array}{l}-8.53 \\
(6.51)\end{array}$ & $\begin{array}{c}9.74 \\
(11.24)\end{array}$ & $\begin{array}{l}-14.35 \\
(10.43)\end{array}$ & $\begin{array}{l}-3.66 \\
(6.85)\end{array}$ & $\begin{array}{l}-5.59 \\
(7.30)\end{array}$ & $\begin{array}{c}-19.13^{*} \\
(9.96)\end{array}$ & $\begin{array}{c}7.11 \\
(6.95)\end{array}$ \\
\hline Observations & 1036 & 1118 & 1115 & 1115 & 1121 & 1117 & 1104 & 1110 \\
\hline R-squared & 0.04 & 0.12 & 0.02 & 0.07 & 0.09 & 0.09 & 0.09 & 0.04 \\
\hline No. of Groups & 354 & 375 & 375 & 375 & 375 & 375 & 375 & 375 \\
\hline Av. Obs. per Group & 2.93 & 2.98 & 2.97 & 2.97 & 2.99 & 2.98 & 2.94 & 2.96 \\
\hline
\end{tabular}

Robust standard errors in parentheses. * significant at $10 \%$;* significant at $5 \%$; *** significant at $1 \%$.

Conflict Index: Material Damage as $0.01 \%$-Points of Total District GDP 
Table 6: Conflict Coefficients for Alternative Specifications

\begin{tabular}{|c|c|c|c|c|c|c|c|c|c|c|c|c|}
\hline \multirow{2}{*}{$\begin{array}{c}\text { Dep. Var: } \\
\text { GDP Growth } \\
\end{array}$} & (1) & (2) & (3) & (4) & (5) & (6) & (7) & (8) & (9) & (10) & (11) & (12) \\
\hline & Agricult. & Mining & Manufact. & Energy & Construct. & Industry & Commerce & Transport & Finance & Services & Service & Total \\
\hline \multicolumn{13}{|l|}{ a. Rural Areas } \\
\hline $\begin{array}{l}\text { Conflict: Material } \\
\text { Damage }\end{array}$ & $\begin{array}{l}-0.24 \\
(0.35)\end{array}$ & $\begin{array}{l}-0.18 \\
(0.41)\end{array}$ & $\begin{array}{c}-1.31 * * \\
(0.51)\end{array}$ & $\begin{array}{l}-0.05 \\
(0.48)\end{array}$ & $\begin{array}{l}-0.81 \\
(0.59)\end{array}$ & $\begin{array}{c}-1.37 * * \\
(0.60)\end{array}$ & $\begin{array}{l}-0.88^{* *} \\
(0.40)\end{array}$ & $\begin{array}{c}-1.55^{* *} \\
(0.68)\end{array}$ & $\begin{array}{c}-1.66 * * * \\
(0.54)\end{array}$ & $\begin{array}{l}-0.28 \\
(0.32)\end{array}$ & $\begin{array}{c}-1.01 * * * \\
(0.33)\end{array}$ & $\begin{array}{c}-1.05^{* * *} \\
(0.38)\end{array}$ \\
\hline $\begin{array}{l}\text { Spillover: Conflict in } \\
\text { Neighboring Districts }\end{array}$ & $\begin{array}{l}-1.15 \\
(1.08) \\
\end{array}$ & $\begin{array}{l}-0.22 \\
(0.99) \\
\end{array}$ & $\begin{array}{r}1.89 \\
(1.59) \\
\end{array}$ & $\begin{array}{l}-1.71 \\
(1.37) \\
\end{array}$ & $\begin{array}{r}2.27 \\
(2.37) \\
\end{array}$ & $\begin{array}{c}1.48 \\
(1.49) \\
\end{array}$ & $\begin{array}{l}-1.11 \\
(1.69) \\
\end{array}$ & $\begin{array}{c}-2.73^{* *} \\
(1.33) \\
\end{array}$ & $\begin{array}{c}-2.74 * * \\
(1.33) \\
\end{array}$ & $\begin{array}{c}2.01 \\
(2.18) \\
\end{array}$ & $\begin{array}{r}0.05 \\
(1.49) \\
\end{array}$ & $\begin{array}{r}0.27 \\
(0.66) \\
\end{array}$ \\
\hline \multicolumn{13}{|l|}{ b. Exclusion of NAD } \\
\hline $\begin{array}{l}\text { Conflict: Material } \\
\text { Damage }\end{array}$ & $\begin{array}{l}-0.54 * \\
(0.29)\end{array}$ & $\begin{array}{l}-0.39 \\
(0.47)\end{array}$ & $\begin{array}{l}-1.31 * \\
(0.74)\end{array}$ & $\begin{array}{l}-0.57 \\
(0.60)\end{array}$ & $\begin{array}{l}-0.17 \\
(0.58)\end{array}$ & $\begin{array}{l}-0.78 \\
(0.56)\end{array}$ & $\begin{array}{c}-0.55 * * * \\
(0.19)\end{array}$ & $\begin{array}{c}-0.65 * * * \\
(0.25)\end{array}$ & $\begin{array}{c}-1.10^{* *} \\
(0.53)\end{array}$ & $\begin{array}{c}-0.63 * * * \\
(0.23)\end{array}$ & $\begin{array}{c}-0.69 * * * \\
(0.16)\end{array}$ & $\begin{array}{c}-0.48 * * \\
(0.19)\end{array}$ \\
\hline $\begin{array}{l}\text { Spillover: Conflict in } \\
\text { Neighboring Districts }\end{array}$ & $\begin{array}{l}-0.31 \\
(0.82)\end{array}$ & $\begin{array}{l}-1.20 \\
(1.01)\end{array}$ & $\begin{array}{l}-0.46 \\
(0.79)\end{array}$ & $\begin{array}{c}0.99 \\
(1.51)\end{array}$ & $\begin{array}{l}-0.91 \\
(0.86)\end{array}$ & $\begin{array}{l}-0.73 \\
(0.73)\end{array}$ & $\begin{array}{l}-1.35 \\
(0.93)\end{array}$ & $\begin{array}{l}-1.65^{*} \\
(0.86)\end{array}$ & $\begin{array}{l}-2.28^{*} \\
(1.16)\end{array}$ & $\begin{array}{l}-1.20^{*} \\
(0.67)\end{array}$ & $\begin{array}{l}-1.54^{*} \\
(0.79)\end{array}$ & $\begin{array}{l}-0.39 \\
(0.51)\end{array}$ \\
\hline \multicolumn{13}{|c|}{ c. Fatalities per Capita (All Areas) } \\
\hline $\begin{array}{l}\text { Conflict: Fatalities } \\
\text { per Capita }\end{array}$ & $\begin{array}{l}-0.21 \\
(0.94)\end{array}$ & $\begin{array}{l}-1.57 \\
(1.83)\end{array}$ & $\begin{array}{l}-2.24 \\
(1.40)\end{array}$ & $\begin{array}{c}2.26 \\
(4.50)\end{array}$ & $\begin{array}{l}-3.01 \\
(1.88)\end{array}$ & $\begin{array}{l}-3.15 \\
(2.18)\end{array}$ & $\begin{array}{l}-1.51 \\
(1.34)\end{array}$ & $\begin{array}{l}-1.55 \\
(2.04)\end{array}$ & $\begin{array}{l}-3.57 \\
(2.61)\end{array}$ & $\begin{array}{l}-1.72 \\
(1.21)\end{array}$ & $\begin{array}{l}-2.32 * \\
(1.25)\end{array}$ & $\begin{array}{l}-2.56^{*} \\
(1.37)\end{array}$ \\
\hline $\begin{array}{l}\text { Spillover: Conflict in } \\
\text { Neighboring Districts }\end{array}$ & $\begin{array}{l}-0.29 \\
(0.68)\end{array}$ & $\begin{array}{c}0.16 \\
(0.87)\end{array}$ & $\begin{array}{c}1.37 \\
(1.31)\end{array}$ & $\begin{array}{l}-1.43 \\
(1.79)\end{array}$ & $\begin{array}{l}2.18 \\
(1.76)\end{array}$ & $\begin{array}{c}1.32 \\
(1.16)\end{array}$ & $\begin{array}{l}-1.35 \\
(1.14)\end{array}$ & $\begin{array}{l}-1.86^{* *} \\
(0.78)\end{array}$ & $\begin{array}{l}-0.03 \\
(1.55)\end{array}$ & $\begin{array}{c}1.56 \\
(1.40)\end{array}$ & $\begin{array}{l}-0.06 \\
(0.99)\end{array}$ & $\begin{array}{c}0.48 \\
(0.52)\end{array}$ \\
\hline
\end{tabular}

Each coefficient from a different regression (control variables as in Table 5).

Robust standard errors in parentheses. * significant at $10 \%$; ** significant at $5 \% ; * * *$ significant at $1 \%$.

Conflict Indices: Fatalities per 1.000 Inhabitants. Material Damage as $0.01 \%$-Points of Total District GDP

Table 7: Conflict Coefficients - Solved vs. Ongoing Conflicts

\begin{tabular}{|c|c|c|c|c|c|c|c|c|c|c|c|c|}
\hline \multirow{2}{*}{$\begin{array}{c}\text { Dep. Var: } \\
\text { GDP Growth } \\
\end{array}$} & (1) & (2) & (3) & (4) & $(5)$ & $(6)$ & $(7)$ & (8) & (9) & (10) & (11) & (12) \\
\hline & Agricult. & Mining & Manufact. & Energy & Construct. & Industry & Commerce & Transport & Finance & Services & Service & Total \\
\hline \multicolumn{13}{|c|}{ a. Ongoing vs. Solved Conflicts (All Areas) } \\
\hline $\begin{array}{l}\text { Solved Conflict: } \\
\text { Material Damage }\end{array}$ & $\begin{array}{l}-0.41 \\
(0.60)\end{array}$ & $\begin{array}{c}0.42 \\
(0.69)\end{array}$ & $\begin{array}{l}-1.40 \\
(0.95)\end{array}$ & $\begin{array}{c}0.24 \\
(1.05)\end{array}$ & $\begin{array}{c}0.97 \\
(0.91)\end{array}$ & $\begin{array}{c}0.02 \\
(0.62)\end{array}$ & $\begin{array}{l}-0.36 \\
(0.41)\end{array}$ & $\begin{array}{c}0.21 \\
(0.33)\end{array}$ & $\begin{array}{l}-1.40 \\
(0.88)\end{array}$ & $\begin{array}{c}-1.02 * * * \\
(0.34)\end{array}$ & $\begin{array}{l}-0.65^{*} \\
(0.35)\end{array}$ & $\begin{array}{c}0.11 \\
(0.37)\end{array}$ \\
\hline $\begin{array}{l}\text { Ongoing Conflict: } \\
\text { Material Damage }\end{array}$ & $\begin{array}{c}0.04 \\
(0.43)\end{array}$ & $\begin{array}{l}-1.96 \\
(1.47)\end{array}$ & $\begin{array}{c}-1.42 * * * \\
(0.54)\end{array}$ & $\begin{array}{l}-0.38 \\
(0.68)\end{array}$ & $\begin{array}{c}-2.87 * * * \\
(0.59)\end{array}$ & $\begin{array}{c}-2.93 * * * \\
(0.44)\end{array}$ & $\begin{array}{l}-1.28 * * \\
(0.60)\end{array}$ & $\begin{array}{c}-3.00^{* * *} \\
(0.40)\end{array}$ & $\begin{array}{l}-1.82 \\
(1.38)\end{array}$ & $\begin{array}{c}0.25 \\
(0.39)\end{array}$ & $\begin{array}{c}-1.34^{* *} \\
(0.56)\end{array}$ & \begin{tabular}{|c}
$-2.12 * * *$ \\
$(0.31)$
\end{tabular} \\
\hline $\begin{array}{l}\text { Spillover: Conf } \\
\text { Neighboring Di }\end{array}$ & $\begin{array}{l}-0.76 \\
(0.63) \\
\end{array}$ & $\begin{array}{l}-0.29 \\
(0.75) \\
\end{array}$ & $\begin{array}{r}0.89 \\
(1.00) \\
\end{array}$ & $\begin{array}{l}-0.77 \\
(0.91) \\
\end{array}$ & $\begin{array}{c}1.51 \\
(1.36) \\
\end{array}$ & $\begin{array}{c}1.07 \\
(0.91) \\
\end{array}$ & $\begin{array}{l}-0.36 \\
(0.86) \\
\end{array}$ & $\begin{array}{c}-0.94 \\
(1.00) \\
\end{array}$ & $\begin{array}{r}1.16 \\
(2.25) \\
\end{array}$ & $\begin{array}{r}0.30 \\
(1.24) \\
\end{array}$ & $\begin{array}{r}0.09 \\
(0.76) \\
\end{array}$ & $\begin{array}{r}0.54 \\
(0.45) \\
\end{array}$ \\
\hline \multicolumn{13}{|c|}{ b. Ongoing vs. Solved Conflicts (Rural Areas) } \\
\hline $\begin{array}{l}\text { Solved Conflict: } \\
\text { Material Damage }\end{array}$ & $\begin{array}{l}-0.40 \\
(0.50)\end{array}$ & $\begin{array}{c}0.54 \\
(0.78)\end{array}$ & $\begin{array}{l}-1.57 \\
(1.03)\end{array}$ & $\begin{array}{c}0.37 \\
(1.17)\end{array}$ & $\begin{array}{c}1.19 \\
(0.88)\end{array}$ & $\begin{array}{c}0.03 \\
(0.52)\end{array}$ & $\begin{array}{l}-0.39 \\
(0.46)\end{array}$ & $\begin{array}{c}0.47 \\
(0.37)\end{array}$ & $\begin{array}{l}-1.30 \\
(0.81)\end{array}$ & $\begin{array}{c}-1.30 * * * \\
(0.40)\end{array}$ & $\begin{array}{l}-0.68^{*} \\
(0.41)\end{array}$ & $\begin{array}{l}-0.08 \\
(0.29)\end{array}$ \\
\hline $\begin{array}{l}\text { Ongoing Conflict: } \\
\text { Material Damage }\end{array}$ & $\begin{array}{l}-0.10 \\
(0.47)\end{array}$ & $\begin{array}{l}-1.95 \\
(1.72)\end{array}$ & $\begin{array}{c}-1.11^{* *} \\
(0.52)\end{array}$ & $\begin{array}{l}-0.45 \\
(0.81)\end{array}$ & $\begin{array}{c}-2.55^{* * *} \\
(0.63)\end{array}$ & $\begin{array}{c}-2.59 * * * \\
(0.42)\end{array}$ & $\begin{array}{l}-1.32 * \\
(0.70)\end{array}$ & $\begin{array}{c}-3.33 * * * \\
(0.42)\end{array}$ & $\begin{array}{l}-1.97^{*} \\
(1.05)\end{array}$ & $\begin{array}{c}0.62 \\
(0.54)\end{array}$ & $\begin{array}{c}-1.30^{* *} \\
(0.63)\end{array}$ & $\begin{array}{c}-1.91^{* * *} \\
(0.31)\end{array}$ \\
\hline $\begin{array}{l}\text { Spillover: Conflict in } \\
\text { Neighboring Districts }\end{array}$ & $\begin{array}{l}-1.16 \\
(1.09) \\
\end{array}$ & $\begin{array}{l}-0.09 \\
(1.05) \\
\end{array}$ & $\begin{array}{r}1.87 \\
(1.60) \\
\end{array}$ & $\begin{array}{l}-1.66 \\
(1.37) \\
\end{array}$ & $\begin{array}{r}2.45 \\
(2.44) \\
\end{array}$ & $\begin{array}{r}1.61 \\
(1.53) \\
\end{array}$ & $\begin{array}{l}-1.07 \\
(1.69) \\
\end{array}$ & $\begin{array}{c}-2.57 * * \\
(1.21) \\
\end{array}$ & $\begin{array}{c}-2.71^{* *} \\
(1.34) \\
\end{array}$ & $\begin{array}{l}1.93 \\
(2.09) \\
\end{array}$ & $\begin{array}{r}0.08 \\
(1.49) \\
\end{array}$ & $\begin{array}{r}0.36 \\
(0.70) \\
\end{array}$ \\
\hline \multicolumn{13}{|c|}{ c. Fatalities per Capita - Ongoing vs. Solved Conflicts (All Areas) } \\
\hline$\frac{\text { Solved Conflict: }}{\text { Material Damage }}$ & $\begin{array}{l}-1.88^{*} \\
(1.01)\end{array}$ & $\begin{array}{l}-3.48 \\
(2.31)\end{array}$ & $\begin{array}{c}0.14 \\
(1.40)\end{array}$ & $\begin{array}{c}8.09 \\
(7.36)\end{array}$ & $\begin{array}{c}0.40 \\
(1.70)\end{array}$ & $\begin{array}{c}1.62 \\
(1.24)\end{array}$ & $\begin{array}{l}-1.28 \\
(1.29)\end{array}$ & $\begin{array}{c}0.90 \\
(1.20)\end{array}$ & $\begin{array}{l}1.26 \\
(2.62)\end{array}$ & $\begin{array}{l}-2.11 \\
(1.31)\end{array}$ & $\begin{array}{l}-0.96 \\
(0.95)\end{array}$ & $\begin{array}{c}0.30 \\
(0.95)\end{array}$ \\
\hline $\begin{array}{l}\text { Ongoing Conflict: } \\
\text { Material Damage }\end{array}$ & $\begin{array}{c}0.93 \\
(0.78)\end{array}$ & $\begin{array}{l}2.61 \\
(3.04)\end{array}$ & $\begin{array}{c}-2.97 * * \\
(1.19)\end{array}$ & $\begin{array}{l}-4.76 \\
(4.51)\end{array}$ & $\begin{array}{l}-4.20^{*} \\
(2.25)\end{array}$ & $\begin{array}{c}-6.23 * * * \\
(1.55)\end{array}$ & $\begin{array}{l}-2.25 \\
(1.79)\end{array}$ & $\begin{array}{c}-4.91 * * \\
(2.33)\end{array}$ & $\begin{array}{c}-7.88^{* * *} \\
(1.57)\end{array}$ & $\begin{array}{l}-0.12 \\
(1.43)\end{array}$ & $\begin{array}{c}-3.17^{* *} \\
(1.58)\end{array}$ & $\begin{array}{c}-4.53 * * * \\
(1.35)\end{array}$ \\
\hline $\begin{array}{l}\text { Spillover: Conflict in } \\
\text { Neighboring Districts }\end{array}$ & $\begin{array}{l}-0.63 \\
(1.21) \\
\end{array}$ & $\begin{array}{c}0.40 \\
(1.70) \\
\end{array}$ & $\begin{array}{r}1.82 \\
(3.09) \\
\end{array}$ & $\begin{array}{c}2.06 \\
(6.07) \\
\end{array}$ & $\begin{array}{r}3.84 \\
(3.97) \\
\end{array}$ & $\begin{array}{r}3.13 \\
(2.47) \\
\end{array}$ & $\begin{array}{r}-3.37^{*} \\
(1.89) \\
\end{array}$ & $\begin{array}{l}-2.66^{*} \\
(1.38) \\
\end{array}$ & $\begin{array}{r}1.55 \\
(3.58) \\
\end{array}$ & $\begin{array}{r}1.50 \\
(2.40) \\
\end{array}$ & $\begin{array}{c}-0.82 \\
(1.64) \\
\end{array}$ & $\begin{array}{r}1.10 \\
(1.27) \\
\end{array}$ \\
\hline
\end{tabular}

Each coefficient from a different regression (control variables as in Table 5).

Robust standard errors in parentheses. * significant at 10\%; ** significant at 5\%; *** significant at $1 \%$.

Conflict Indices: Fatalities per 1.000 Inhabitants. Material Damage as $0.01 \%$-Points of Total District GDP 


\section{APPENDIX}

Table I: Structure of the GDP Data

\begin{tabular}{|c|c|c|c|c|}
\hline & Sector & Sub-sector & $\begin{array}{c}\text { GDP Share } 2000 \\
\text { (Rural Areas) }\end{array}$ & $\begin{array}{c}\text { GDP Share } 2008 \\
\text { (Rural Areas) }\end{array}$ \\
\hline \multirow{5}{*}{ 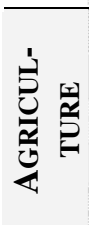 } & \multirow{5}{*}{ Agriculture } & Farm Food Crops & \multirow{5}{*}{$\begin{array}{l}16.7^{\dagger} \\
(27.5)\end{array}$} & \multirow{5}{*}{$\begin{array}{l}15.5 \\
(26.2)\end{array}$} \\
\hline & & Estate Crops & & \\
\hline & & Livestock & & \\
\hline & & Forestry & & \\
\hline & & Fishery & & \\
\hline \multirow{20}{*}{ 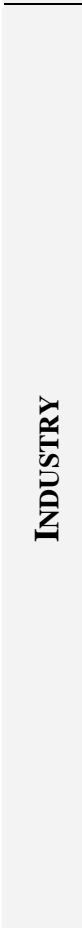 } & \multirow{3}{*}{ Mining } & Mining (Oil) & \multirow{3}{*}{$\begin{array}{c}11.1 \\
(18.8)\end{array}$} & \multirow{3}{*}{$\begin{array}{c}8.5 \\
(14.8)\end{array}$} \\
\hline & & Mining (Others) & & \\
\hline & & Quarrying & & \\
\hline & \multirow{13}{*}{ Manufacturing } & Oil \& Gas Manufacturing & \multirow{13}{*}{$\begin{array}{l}26.3 \\
(21.7)\end{array}$} & \multirow{13}{*}{$\begin{array}{l}24.3 \\
(22.2)\end{array}$} \\
\hline & & - Petroleum Refinery & & \\
\hline & & - Liguified Natural Gas & & \\
\hline & & Non Oil \& Gas Manufacturing & & \\
\hline & & - Food, Beverage \& Tobacco & & \\
\hline & & - Textile, Leather Products \& Footwear & & \\
\hline & & - Wood Products \& Forest Products & & \\
\hline & & - Paper & & \\
\hline & & - Fertilizer, Chemicals \& Rubber Products & & \\
\hline & & - Cements and Non-metal Quarrying Products & & \\
\hline & & - Iron \& Steel & & \\
\hline & & - Transport. Vehicle, Machinery \& Equipment & & \\
\hline & & - Other Manufactured Products & & \\
\hline & \multirow{3}{*}{ Energy } & Electricity & \multirow{3}{*}{$\begin{array}{l}1.0 \\
(0.9)\end{array}$} & \multirow{3}{*}{$\begin{array}{l}1.1 \\
(1.0)\end{array}$} \\
\hline & & Gas & & \\
\hline & & Water Supply & & \\
\hline & Construction & Construction Total & $\begin{array}{c}5.1 \\
(3.3)\end{array}$ & $\begin{array}{c}5.9 \\
(3.9)\end{array}$ \\
\hline \multirow{25}{*}{ 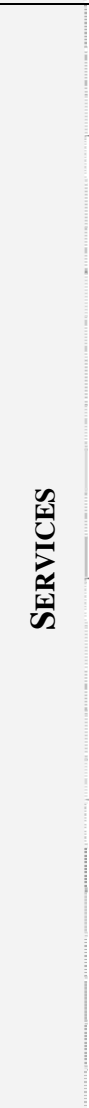 } & \multirow{3}{*}{ Commerce } & Large Trade \& Retail & \multirow{3}{*}{$\begin{array}{c}17.5 \\
(14.5)\end{array}$} & \multirow{3}{*}{$\begin{array}{c}20.0 \\
(16.5)\end{array}$} \\
\hline & & Hotel & & \\
\hline & & Restaurant & & \\
\hline & \multirow{10}{*}{$\begin{array}{c}\text { Transport \& } \\
\text { Communication }\end{array}$} & Transportation & \multirow{10}{*}{$\begin{array}{c}5.2 \\
(3.4)\end{array}$} & \multirow{10}{*}{$\begin{array}{c}6.9 \\
(4.0)\end{array}$} \\
\hline & & - Railway Transport & & \\
\hline & & - Road Transport & & \\
\hline & & - Sea Water Transport & & \\
\hline & & - Inland Water Transport & & \\
\hline & & - Air Transport & & \\
\hline & & - Transportation Supporting & & \\
\hline & & Communication & & \\
\hline & & - Post and Telecommunication & & \\
\hline & & - Communication Supporting & & \\
\hline & & Banking & & \\
\hline & & Non-banking Financial Institution & & \\
\hline & Finance & Financial Supporting & $\begin{array}{l}8.6 \\
(27)\end{array}$ & 8.8 \\
\hline & & Rent of Building & & \\
\hline & & Business Services & & \\
\hline & & General Government & & \\
\hline & & - Government Administration \& Defense & & \\
\hline & & - Other Government Services & & \\
\hline & Services & Private & $\begin{array}{l}8.5 \\
(72)\end{array}$ & 9.0 \\
\hline & & - Social Community & & \\
\hline & & - Recreation \& Entertainment & & \\
\hline & & - Household \& Private & & \\
\hline
\end{tabular}

\footnotetext{
${ }^{\dagger}$ Percentage share of total (rural) GDP.
} 
Table II: Alternative Conflict Coefficients

\begin{tabular}{|c|c|c|c|c|c|c|c|c|c|c|c|c|}
\hline \multirow{2}{*}{$\begin{array}{c}\text { Dep. Var: } \\
\text { GDP Growth } \\
\end{array}$} & (1) & $(2)$ & (3) & (4) & (5) & (6) & (7) & (8) & (9) & (10) & (11) & (12) \\
\hline & Agricult. & Mining & Manufact. & Energy & Construct. & Industry & Commerce & Transport & Finance & Services & Service & Total \\
\hline \multicolumn{13}{|c|}{ a. Share of Villages Affected by Conflict } \\
\hline $\begin{array}{l}\text { Conflict: Material } \\
\text { Damage }\end{array}$ & $\begin{array}{c}2.72 \\
(3.01)\end{array}$ & $\begin{array}{c}1.03 \\
(5.03)\end{array}$ & $\begin{array}{c}2.69 \\
(5.71)\end{array}$ & $\begin{array}{c}1.51 \\
(7.51)\end{array}$ & $\begin{array}{c}4.95 \\
(9.12)\end{array}$ & $\begin{array}{c}0.14 \\
(5.80)\end{array}$ & $\begin{array}{l}-5.68 \\
(4.07)\end{array}$ & $\begin{array}{l}-1.91 \\
(4.18)\end{array}$ & $\begin{array}{l}-7.05 \\
(5.73)\end{array}$ & $\begin{array}{l}-2.15 \\
(3.31)\end{array}$ & $\begin{array}{l}-4.66^{*} \\
(2.72)\end{array}$ & $\begin{array}{l}-1.20 \\
(2.98)\end{array}$ \\
\hline $\begin{array}{l}\text { Spillover: Conflict in } \\
\text { Neighboring Districts }\end{array}$ & $\begin{array}{r}1.17 \\
(3.09) \\
\end{array}$ & $\begin{array}{c}6.64 \\
(5.68) \\
\end{array}$ & $\begin{array}{r}3.80 \\
(4.94) \\
\end{array}$ & $\begin{array}{l}-4.90 \\
(5.82) \\
\end{array}$ & $\begin{array}{r}5.62 \\
(4.85) \\
\end{array}$ & $\begin{array}{l}8.67 * \\
(4.61) \\
\end{array}$ & $\begin{array}{r}0.05 \\
(3.21) \\
\end{array}$ & $\begin{array}{l}-1.22 \\
(4.02) \\
\end{array}$ & $\begin{array}{c}0.83 \\
(6.70) \\
\end{array}$ & $\begin{array}{l}-2.04 \\
(4.81) \\
\end{array}$ & $\begin{array}{l}-1.06 \\
(2.78) \\
\end{array}$ & $\begin{array}{l}4.65^{*} \\
(2.81) \\
\end{array}$ \\
\hline \multicolumn{13}{|c|}{ b. Material Damage - Absolute Values } \\
\hline $\begin{array}{l}\text { Conflict: Material } \\
\text { Damage }\end{array}$ & $\begin{array}{c}0.02 \\
(0.22)\end{array}$ & $\begin{array}{l}-0.34 \\
(0.81)\end{array}$ & $\begin{array}{l}-0.39 \\
(0.26)\end{array}$ & $\begin{array}{c}0.07 \\
(0.22)\end{array}$ & $\begin{array}{l}-0.71 * \\
(0.42)\end{array}$ & $\begin{array}{c}-0.91 * * \\
(0.37)\end{array}$ & $\begin{array}{c}-0.67^{* * *} \\
(0.16)\end{array}$ & $\begin{array}{c}-1.17 * * * \\
(0.23)\end{array}$ & $\begin{array}{c}-1.41 * * * \\
(0.23)\end{array}$ & $\begin{array}{l}-0.18 \\
(0.23)\end{array}$ & $\begin{array}{c}-0.76^{* * *} \\
(0.11)\end{array}$ & $\begin{array}{c}-0.80 * * * \\
(0.22)\end{array}$ \\
\hline $\begin{array}{l}\text { Spillover: Conflict in } \\
\text { Neighboring Districts }\end{array}$ & $\begin{array}{l}-0.47 \\
(0.33) \\
\end{array}$ & $\begin{array}{c}0.33 \\
(0.59) \\
\end{array}$ & $\begin{array}{r}0.96 \\
(0.94) \\
\end{array}$ & $\begin{array}{l}-1.02 \\
(0.79) \\
\end{array}$ & $\begin{array}{r}1.70 \\
(1.37) \\
\end{array}$ & $\begin{array}{r}1.06 \\
(0.85) \\
\end{array}$ & $\begin{array}{l}-0.40 \\
(0.74) \\
\end{array}$ & $\begin{array}{l}-0.56 \\
(0.53) \\
\end{array}$ & $\begin{array}{c}1.01 \\
(1.20) \\
\end{array}$ & $\begin{array}{r}0.35 \\
(0.88) \\
\end{array}$ & $\begin{array}{l}-0.01 \\
(0.58) \\
\end{array}$ & $\begin{array}{r}0.46 \\
(0.34) \\
\end{array}$ \\
\hline \multicolumn{13}{|c|}{ c. Fatalities - Absolute Numbers } \\
\hline $\begin{array}{l}\text { Conflict: Number of } \\
\text { Fatalities }\end{array}$ & $\begin{array}{l}-0.11 \\
(0.19)\end{array}$ & $\begin{array}{l}-0.70^{*} \\
(0.39)\end{array}$ & $\begin{array}{l}-0.20 \\
(0.36)\end{array}$ & $\begin{array}{c}0.89 \\
(1.33)\end{array}$ & $\begin{array}{l}-0.52 \\
(0.48)\end{array}$ & $\begin{array}{l}-0.55 \\
(0.67)\end{array}$ & $\begin{array}{c}-0.65^{* *} \\
(0.28)\end{array}$ & $\begin{array}{l}-0.66 \\
(0.64)\end{array}$ & $\begin{array}{l}-0.75 \\
(0.88)\end{array}$ & $\begin{array}{l}-0.21 \\
(0.21)\end{array}$ & $\begin{array}{c}-0.64 * * \\
(0.32)\end{array}$ & $\begin{array}{l}-0.61 \\
(0.44)\end{array}$ \\
\hline $\begin{array}{l}\text { Spillover: Conflict in } \\
\text { Neighboring Districts }\end{array}$ & $\begin{array}{l}-0.21 \\
(0.22)\end{array}$ & $\begin{array}{c}0.35 \\
(0.32)\end{array}$ & $\begin{array}{c}0.16 \\
(0.71)\end{array}$ & $\begin{array}{c}0.99 \\
(1.63)\end{array}$ & $\begin{array}{c}0.65 \\
(0.97)\end{array}$ & $\begin{array}{c}0.52 \\
(0.55)\end{array}$ & $\begin{array}{c}-0.85^{* *} \\
(0.39)\end{array}$ & $\begin{array}{c}-0.74 * * \\
(0.36)\end{array}$ & $\begin{array}{c}0.15 \\
(0.78)\end{array}$ & $\begin{array}{c}0.26 \\
(0.50)\end{array}$ & $\begin{array}{l}-0.34 \\
(0.33)\end{array}$ & $\begin{array}{c}0.06 \\
(0.29)\end{array}$ \\
\hline
\end{tabular}

Each coefficient from a different regression (control variables as in Table 5).

Robust standard errors in parentheses. * significant at $10 \%$; $*$ significant at $5 \% ; * * *$ significant at $1 \%$.

Conflict Indices: Number of Fatalities (in 100 deaths). Material Damage (in 1 billion Rupiah).

Table III: Unchanged GDP Data

\begin{tabular}{|c|c|c|c|c|c|c|c|c|c|c|c|c|}
\hline \multirow{2}{*}{$\begin{array}{c}\text { Dep. Var: } \\
\text { GDP Growth } \\
\end{array}$} & (1) & (2) & (3) & (4) & (5) & (6) & (7) & (8) & (9) & (10) & (11) & (12) \\
\hline & Agricult. & Mining & Manufact. & Energy & Construct. & Industry & Commerce & Transport & Finance & Services & Service & Total \\
\hline \multicolumn{13}{|l|}{ a. All Areas } \\
\hline $\begin{array}{l}\text { Conflict: Material } \\
\text { Damage }\end{array}$ & $\begin{array}{l}-0.29 \\
(0.29)\end{array}$ & $\begin{array}{l}-0.10 \\
(1.30)\end{array}$ & $\begin{array}{c}-1.49 * * * \\
(0.49)\end{array}$ & $\begin{array}{l}-0.06 \\
(0.50)\end{array}$ & $\begin{array}{l}-0.99 \\
(0.90)\end{array}$ & $\begin{array}{l}-1.74 * * \\
(0.79)\end{array}$ & $\begin{array}{l}-0.83 * \\
(0.44)\end{array}$ & $\begin{array}{l}-1.31 \\
(0.82)\end{array}$ & $\begin{array}{l}-0.68 \\
(1.06)\end{array}$ & $\begin{array}{l}-1.84 \\
(2.03)\end{array}$ & $\begin{array}{c}-1.43^{* *} \\
(0.61)\end{array}$ & $\begin{array}{c}-1.80^{* *} \\
(0.76)\end{array}$ \\
\hline $\begin{array}{l}\text { Spillover: Conflict in } \\
\text { Neighboring Districts }\end{array}$ & $\begin{array}{l}-0.46 \\
(0.67) \\
\end{array}$ & $\begin{array}{l}-6.91 \\
(7.76) \\
\end{array}$ & $\begin{array}{r}0.81 \\
(0.89) \\
\end{array}$ & $\begin{array}{l}-1.51 \\
(1.57) \\
\end{array}$ & $\begin{array}{c}-0.22 \\
(1.52) \\
\end{array}$ & $\begin{array}{c}0.02 \\
(2.73) \\
\end{array}$ & $\begin{array}{l}-0.46 \\
(0.90) \\
\end{array}$ & $\begin{array}{l}-0.01 \\
(0.84) \\
\end{array}$ & $\begin{array}{r}-6.04 \\
(7.43) \\
\end{array}$ & $\begin{array}{l}-1.77 \\
(3.27) \\
\end{array}$ & $\begin{array}{r}-0.30 \\
(1.23) \\
\end{array}$ & $\begin{array}{c}1.03 \\
(1.70) \\
\end{array}$ \\
\hline \multicolumn{13}{|l|}{ b. Rural Areas } \\
\hline $\begin{array}{l}\text { Conflict: Material } \\
\text { Damage }\end{array}$ & $\begin{array}{l}-0.38 \\
(0.27)\end{array}$ & $\begin{array}{l}-0.14 \\
(1.48)\end{array}$ & $\begin{array}{c}-1.49 * * * \\
(0.49)\end{array}$ & $\begin{array}{l}-0.08 \\
(0.53)\end{array}$ & $\begin{array}{l}-0.88 \\
(0.96)\end{array}$ & $\begin{array}{c}-1.64^{* *} \\
(0.83)\end{array}$ & $\begin{array}{c}-0.86^{* *} \\
(0.43)\end{array}$ & $\begin{array}{l}-1.32 \\
(0.86)\end{array}$ & $\begin{array}{l}-0.82 \\
(0.87)\end{array}$ & $\begin{array}{l}-1.84 \\
(2.13)\end{array}$ & $\begin{array}{c}-1.44^{* *} \\
(0.62)\end{array}$ & $\begin{array}{c}-1.81 * * \\
(0.78)\end{array}$ \\
\hline $\begin{array}{l}\text { Spillover: Conflict in } \\
\text { Neighboring Districts }\end{array}$ & $\begin{array}{l}-1.37 \\
(1.26) \\
\end{array}$ & $\begin{array}{l}-12.52 \\
(14.24)\end{array}$ & $\begin{array}{c}1.80 \\
(1.63) \\
\end{array}$ & $\begin{array}{l}-3.19 \\
(2.88)\end{array}$ & $\begin{array}{l}-0.75 \\
(2.94) \\
\end{array}$ & $\begin{array}{c}-0.23 \\
(5.28) \\
\end{array}$ & $\begin{array}{l}-1.27 \\
(1.74) \\
\end{array}$ & $\begin{array}{r}-0.40 \\
(1.53) \\
\end{array}$ & $\begin{array}{l}-15.06 \\
(11.96)\end{array}$ & $\begin{array}{l}-3.69 \\
(6.07) \\
\end{array}$ & $\begin{array}{l}-1.15 \\
(2.39) \\
\end{array}$ & $\begin{array}{c}1.35 \\
(3.24)\end{array}$ \\
\hline \multicolumn{13}{|c|}{ c. Ongoing vs. Solved Conflicts } \\
\hline $\begin{array}{l}\text { Solved Conflict: } \\
\text { Material Damage }\end{array}$ & $\begin{array}{l}-0.35 \\
(0.61)\end{array}$ & $\begin{array}{l}-4.39 \\
(4.59)\end{array}$ & $\begin{array}{l}-1.60 \\
(0.98)\end{array}$ & $\begin{array}{c}0.04 \\
(1.04)\end{array}$ & $\begin{array}{c}0.77 \\
(1.03)\end{array}$ & $\begin{array}{l}-0.41 \\
(1.06)\end{array}$ & $\begin{array}{l}-0.17 \\
(0.45)\end{array}$ & $\begin{array}{c}0.39 \\
(0.42)\end{array}$ & $\begin{array}{l}-0.39 \\
(1.03)\end{array}$ & $\begin{array}{l}-3.16 \\
(3.67)\end{array}$ & $\begin{array}{l}-1.08 \\
(1.41)\end{array}$ & $\begin{array}{c}0.27 \\
(0.48)\end{array}$ \\
\hline $\begin{array}{l}\text { Ongoing Conflict: } \\
\text { Material Damage }\end{array}$ & $\begin{array}{l}-0.28 \\
(0.39)\end{array}$ & $\begin{array}{l}3.56 \\
(2.57)\end{array}$ & $\begin{array}{c}-1.43 * * * \\
(0.41)\end{array}$ & $\begin{array}{l}-0.17 \\
(0.60)\end{array}$ & $\begin{array}{c}-2.46 * * * \\
(0.74)\end{array}$ & $\begin{array}{c}-2.84 * * * \\
(0.74)\end{array}$ & $\begin{array}{c}-1.39 * * * \\
(0.51)\end{array}$ & $\begin{array}{c}-2.76^{* * *} \\
(0.54)\end{array}$ & $\begin{array}{l}-0.97 \\
(1.96)\end{array}$ & $\begin{array}{l}-0.74 \\
(2.81)\end{array}$ & $\begin{array}{c}-1.73 * * \\
(0.72)\end{array}$ & $\begin{array}{c}-3.57 * * * \\
(0.41)\end{array}$ \\
\hline $\begin{array}{l}\text { Spillover: Conflict in } \\
\text { Neighboring Districts }\end{array}$ & $\begin{array}{l}-0.46 \\
(0.69)\end{array}$ & $\begin{array}{l}-7.65 \\
(8.10)\end{array}$ & $\begin{array}{c}0.80 \\
(0.90)\end{array}$ & $\begin{array}{l}-1.49 \\
(1.62)\end{array}$ & $\begin{array}{c}0.07 \\
(1.59)\end{array}$ & $\begin{array}{c}0.24 \\
(2.72)\end{array}$ & $\begin{array}{l}-0.35 \\
(0.91)\end{array}$ & $\begin{array}{c}0.28 \\
(0.89)\end{array}$ & $\begin{array}{l}-5.98 \\
(7.44)\end{array}$ & $\begin{array}{l}-1.99 \\
(3.22)\end{array}$ & $\begin{array}{l}-0.24 \\
(1.19)\end{array}$ & $\begin{array}{c}1.38 \\
(1.69)\end{array}$ \\
\hline
\end{tabular}

Each coefficient from a different regression (control variables as in Table 5).

Robust standard errors in parentheses. * significant at $10 \% ; * *$ significant at $5 \%$; *** significant at $1 \%$.

Conflict Indices: Fatalities per 1.000 Inhabitants. Material Damage as $0.01 \%$-Points of Total District GDP 